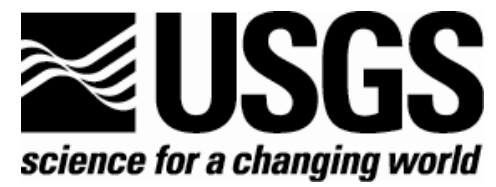

U.S. GEOLOGICAL SURVEY GREATER EVERGLADES PRIORITY ECOSYSTEM SCIENCES PROGRAM

\title{
Simulation of Integrated Surface-Water/Ground- Water Flow and Salinity for a Coastal Wetland and Adjacent Estuary
}

By Christian D. Langevin, Eric D. Swain, and Melinda A. Wolfert

Open-File Report 2004-1097

U.S. Department of the Interior

U.S. Geological Survey 


\title{
U.S. Department of the Interior Gale A. Norton, Secretary
}

\author{
U.S. Geological Survey \\ Charles G. Groat, Director
}

U.S. Geological Survey, Reston, Virginia: 2004

For sale by U.S. Geological Survey, Information Services

Box 25286, Denver Federal Center

Denver, CO 80225

For more information about the USGS and its products:

Telephone: 1-888-ASK-USGS

World Wide Web: http://www.usgs.gov/

Any use of trade, product, or firm names in this publication is for descriptive purposes only and does not imply endorsement by the U.S. Government.

Although this report is in the public domain, permission must be secured from the individual copyright owners to reproduce any copyrighted materials contained within this report. 


\section{Contents}

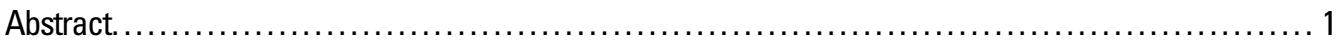

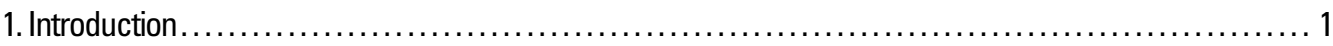

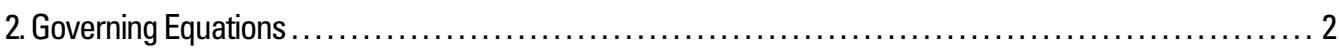

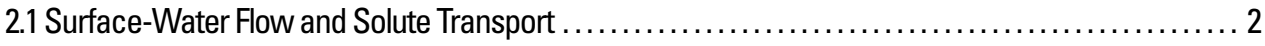

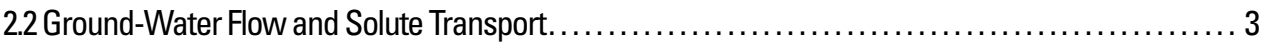

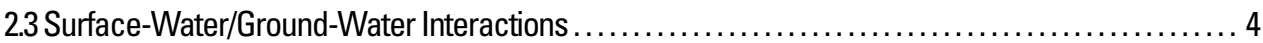

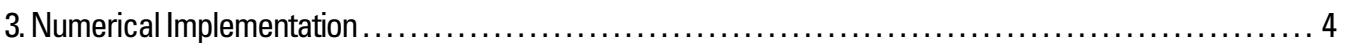

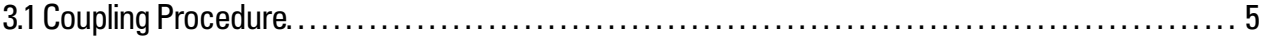

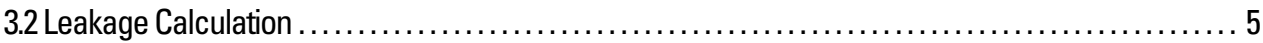

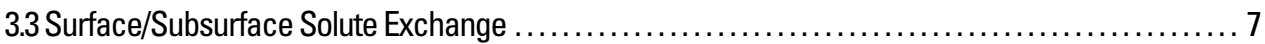

3.4 Spatially Distributed Rainfall and Evapotranspiration ................................ 7

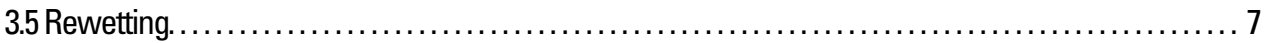

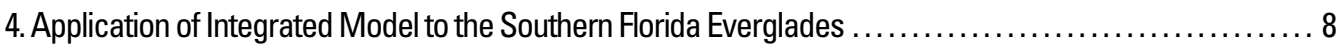

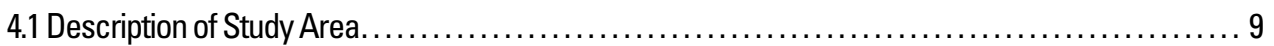

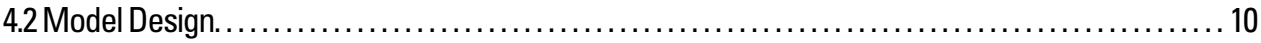

4.3 Model Calibration and Analysis of Simulation Results.............................. 13

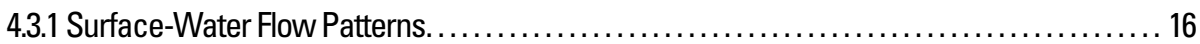

4.3.2 Discharge to Florida Bay and Surface-Water/Ground-Water Interactions............. 17

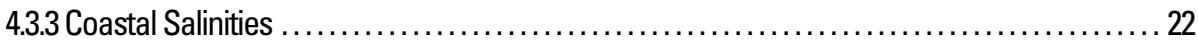

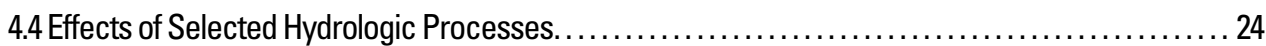

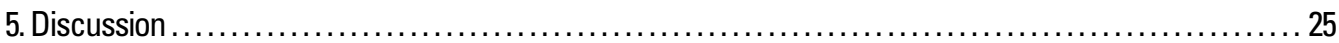

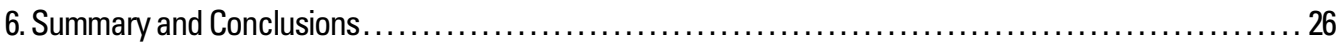

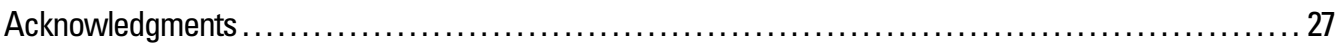

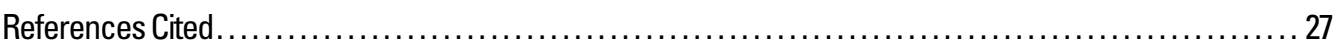

\section{Figures}

1. Schematic of conceptual model for surface-water and ground-water interactions. ..............2

2. Schematic showing relation between surface-water and ground-water timesteps .............5

3. Diagram of a surface-water cell and an uppermost aquifer cell. ...........................

4-9. Maps showing:

4. Study area including location of Taylor Slough, Florida Bay, monitoring stations,

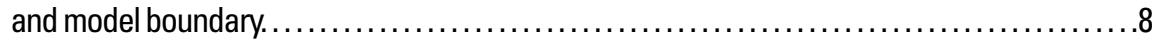

5. Grid of land-surface elevation, relative to the North American Vertical Datum of 1988

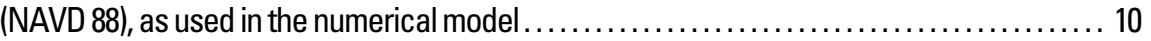

6. Model grid and index numbers for model boundaries ........................... 11

7. Annual average surface-water budget for the coastal wetland for the

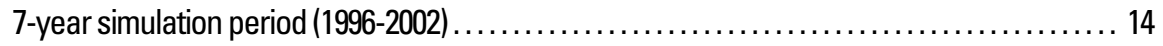

8. Daily average surface-water flow velocities for November 20, 1999,

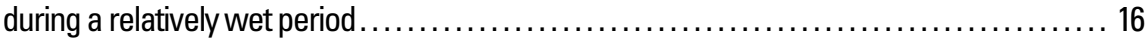

9. Daily average surface-water flow velocities for June 24,2000 , during a relatively dry period. 
10. Graph showing measured and simulated cumulative discharge for the five measured creeks, Trout Creek, and the five creeks without continuous measurements for the 7-year simulation period (1996-2002) .

11. Pie chart showing ranking of the coastal creeks by cumulative discharge volume to Florid

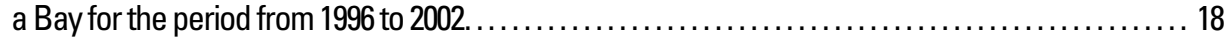

12-15. Graphs showing:

12. Measured and simulated monthly discharge at Trout Creek from 1996 to $2002 \ldots \ldots \ldots \ldots \ldots$

13. Measured and simulated average daily discharge at Trout Creek for $1999 . \ldots \ldots \ldots \ldots \ldots \ldots$

14. Amplitude spectrum as a function of frequency calculated using 2-hour measured and simulated discharges at Trout Creek for the 7-year simulation period ...

15. Discharge over Buttonwood Embankment and stage at Taylor River during Hurricane Irene, October 1999.

16. Map showing average annual leakage rates for the 7 -year simulation period $\ldots \ldots \ldots \ldots \ldots \ldots \ldots \ldots \ldots \ldots$

17. Graphs showing simulated leakage rates, surface-water stage, and ground-water head at four locations.

18. Map showing daily average surface-water salinities for November 20, 1999, during a relatively wet period.

19. Map showing daily average surface-water salinities for June 24,2000 , during a relatively dry period....

20. Graph showing measured and simulated values of monthly average salinity at Trout Creek for the 7-year simulation period (1996-2002).

21. Graph showing average daily salinity at Trout Creek from simulation without local wind stress, the base case simulation, and from measured data. ...

\section{Tables}

1. Description of boundary conditions for the surface-water model. $\ldots \ldots \ldots \ldots \ldots \ldots \ldots \ldots \ldots \ldots \ldots \ldots \ldots \ldots \ldots \ldots$

2. Calibration statistics for daily average coastal creek discharges, surface-water stage or

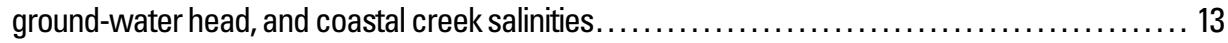

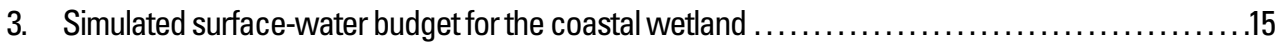

4. Calibration statistics for the surface-water simulation without leakage ...................... 24 


\section{Conversion Factors, Acronyms, and Datums}

\begin{tabular}{|c|c|c|}
\hline Multiply & By & To obtain \\
\hline \multicolumn{3}{|c|}{ Length } \\
\hline centimeter $(\mathrm{cm})$ & 0.3937 & inch (in.) \\
\hline millimeter $(\mathrm{mm})$ & 0.03937 & inch (in.) \\
\hline meter $(\mathrm{m})$ & 3.281 & foot $(\mathrm{ft})$ \\
\hline kilometer $(\mathrm{km})$ & 0.6214 & mile (mi) \\
\hline \multicolumn{3}{|c|}{ Area } \\
\hline square meter $\left(\mathrm{m}^{2}\right)$ & 10.76 & square foot $\left(\mathrm{ft}^{2}\right)$ \\
\hline square kilometer $\left(\mathrm{km}^{2}\right)$ & 0.3861 & square mile $\left(\mathrm{mi}^{2}\right)$ \\
\hline \multicolumn{3}{|c|}{ Volume } \\
\hline cubic meter $\left(\mathrm{m}^{3}\right)$ & 35.31 & cubic foot $\left(\mathrm{ft}^{3}\right)$ \\
\hline \multicolumn{3}{|c|}{ Flow rate } \\
\hline cubic meter per year $\left(\mathrm{m}^{3} / \mathrm{yr}\right)$ & 0.000811 & acre-foot per year (acre-ft/yr) \\
\hline meter per second $(\mathrm{m} / \mathrm{s})$ & 3.281 & foot per second (ft/s) \\
\hline meter per day $(\mathrm{m} / \mathrm{d})$ & 3.281 & foot per day $(\mathrm{ft} / \mathrm{d})$ \\
\hline cubic meter per day $\left(\mathrm{m}^{3} / \mathrm{d}\right)$ & 35.31 & cubic foot per day $\left(\mathrm{ft}^{3} / \mathrm{d}\right)$ \\
\hline millimeter per year $(\mathrm{mm} / \mathrm{yr})$ & 0.03937 & inch per year (in/yr) \\
\hline \multicolumn{3}{|c|}{ Hydraulic conductivity } \\
\hline meter per day $(\mathrm{m} / \mathrm{d})$ & 3.281 & foot per day $(\mathrm{ft} / \mathrm{d})$ \\
\hline \multicolumn{3}{|c|}{ Transmissivity } \\
\hline meter squared per day $\left(\mathrm{m}^{2} / \mathrm{d}\right)$ & 10.76 & foot squared per day $\left(\mathrm{ft}^{2} / \mathrm{d}\right)$ \\
\hline \multicolumn{3}{|c|}{ Other units } \\
\hline meter per second $(\mathrm{mm} / \mathrm{s})$ & 0.3937 & inch per second (in./s) \\
\hline centimeter per day $(\mathrm{cm} / \mathrm{d})$ & 0.3937 & inch per day (in./d) \\
\hline centimeter per year $(\mathrm{cm} / \mathrm{yr})$ & 0.3937 & inch per year (in./yr) \\
\hline
\end{tabular}

$\begin{aligned} \text { ADI } & \text { Alternating Direction Implicit } \\ \text { GPS } & \text { Global Positioning System } \\ \text { ME } & \text { Mean Error } \\ \text { MAE } & \text { Mean Absolute Error } \\ \text { NF } & \text { No-Flow Boundary } \\ \text { RMSE } & \text { Root Mean Square Error } \\ \text { psu } & \text { practical salinity unit } \\ \text { WL } & \text { Specified Water-Level Boundary }\end{aligned}$

Temperature in degrees Celsius $\left({ }^{\circ} \mathrm{C}\right)$ may be converted to degrees Fahrenheit $\left({ }^{\circ} \mathrm{F}\right)$ as follows:

${ }^{\circ} \mathrm{F}=\left(1.8 \times^{\circ} \mathrm{C}\right)+32$

Vertical coordinate information is referenced to the North American Vertical Datum of 1988 (NAVD 88). Horizontal coordinate information is referenced to the North American Datum of 1927 (NAD 27).

Altitude, as used in this report, refers to distance above the vertical datum. 



\title{
Simulation of Integrated Surface-Water/Ground- Water Flow and Salinity for a Coastal Wetland and Adjacent Estuary
}

\author{
By Christian D. Langevin, Eric D. Swain, and Melinda A. Wolfert
}

\begin{abstract}
The SWIFT2D surface-water flow and transport code, which solves the St. Venant equations in two dimensions, was coupled with the SEAWAT variable-density ground-water code to represent hydrologic processes in coastal wetlands and adjacent estuaries. The integrated code was applied to the southern Everglades of Florida to quantify flow and salinity patterns and to evaluate effects of hydrologic processes. Results indicate that most surface water within Taylor Slough flows through Joe Bay and into Florida Bay through Trout Creek. Overtopping of the Buttonwood Embankment, a narrow but continuous ridge that separates the coastal wetlands from Florida Bay, does occur in response to tropical storms, but the net overflow is only 1.5 percent of creek discharge. The net leakage rate for the coastal wetland is about zero with nearly equal upward $(17.1 \mathrm{~cm} / \mathrm{yr})$ and downward $(17.4 \mathrm{~cm} / \mathrm{yr})$ rates. During the dry season, the coastal wetland increases in salinity to 30-35 practical salinity units but is flushed each year with the onset of the wet season. Model results demonstrate that surface-water/ground-water interactions, density-dependent flow, and wind affect flow and salinity patterns.
\end{abstract}

\section{Introduction}

Coastal wetlands are a difficult hydrologic environment to represent with a numerical model because of the large number of contributing hydrologic processes, shallow hydraulic gradients, and variable-density flow conditions. Existing numerical modeling strategies have been developed for either the freshwater wetland system or the estuary, but simulations rarely span both domains. Recently, distributed-parameter physics-based computer codes have been developed to simulate coupled surface-water and ground-water flow for inland freshwater systems. Examples include: InHM (VanderKwaak, 1999; VanderKwaak and Loague, 2001), MIKE SHE (Graham and Refsgaard, 2001), MODHMS (HydroGeoLogic Inc., 2003; Panday and Huyakorn, 2004), and WASH123 (Yeh and Huang, 2003). To simplify surface and subsurface coupling techniques and to minimize computer runtimes, many integrated models use the diffusive wave approximation to the St. Venant equation to represent overland flow. The diffusive wave approximation, in which the convective and local acceleration terms are neglected, is normally a valid approximation for inland systems due to relatively high frictional resistances, small flow velocities, and shallow flow depths. Most integrated models are also based on the assumption of constant fluid density, and thus their applicability to coastal regions is questionable unless it can somehow be shown that model results are insensitive to density variations. Conversely, estuary and oceanic models typically solve the full St. Venant equations because the convective and local acceleration terms are significant under tidal and wind-driven conditions. Furthermore, most estuarine and oceanic models contain options for including the effects of density on surface-water flow, and have transport capabilities to simulate salinity. Estuarine and oceanic models, however, normally assume ground-water exchanges are negligible, or that the exchanges can be represented as a simple source term (Wang and others, 2003; Brown and others, 2003). Thus, most of the existing codes are not well suited to represent both the inland and marine systems, and the coastal wetlands that separate them. 


\section{Simulation of Integrated Surface-Water/Ground-Water Flow and Salinity for a Coastal Wetland and Adjacent Estuary}

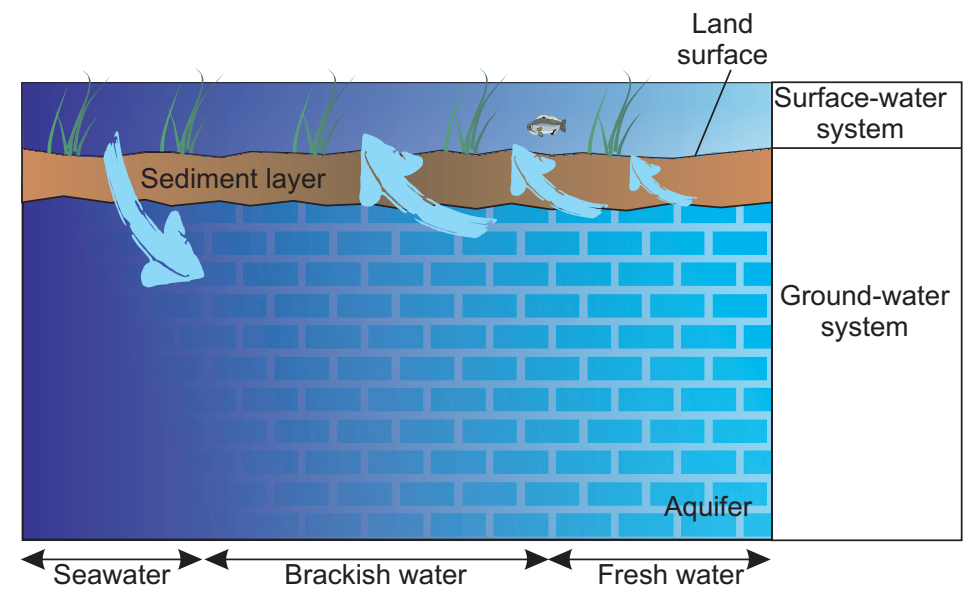

Figure 1. Conceptual model for surface-water and ground-water interactions.

ical procedure for implementing the two codes in a coupled framework. Lastly, the integrated code is applied to the southern Everglades of Florida and northeastern Florida Bay to quantify flow and salinity patterns for a 7-year period (1996-2002) and to examine the effects of selected hydrologic processes.

\section{Goveming Equations}

The subsequent governing equations are well described in the literature, and have been selected to represent hydrologic processes in coastal wetlands and adjacent estuaries. The two-dimensional vertically averaged flow equations are used for the surface flow as a compromise that allows better horizontal resolution at the cost of vertical resolution. This is justified by the observation that in coastal wetlands, it is important to accurately represent topographic relief, because variations in ground-surface elevations are of the same order as water depths, while the shallow depths make baroclinic driving - a main cause of third-dimension flow-highly ineffectual. The equations used to couple the surface-water model with the ground-water model assume that unsaturated zones are thin to absent, and leakage to the water table can, therefore, be treated as instantaneous. This assumption may limit the approach to areas with shallow water tables and highly porous materials.

\section{Surface-Water Flow and Solute Transport}

The governing equations for a shallow surface-water system consist of conservation of mass, volume, and momentum. Leendertse and Gritton (1971) and Leendertse (1987) present the following governing equations, which were modified by Swain and others (2004) to include aerially distributed sources and sinks, describing the: (1) conservation of water volume, (2) conservation of momentum in the $x$-direction, (3) conservation of momentum in the $y$-direction, and (4) solute mass transport:

$$
\begin{gathered}
\frac{\partial h}{\partial t}+\frac{\partial}{\partial x}\left(d v_{x}\right)+\frac{\partial}{\partial y}\left(d v_{y}\right)+q_{s g}+q_{r}+q_{e t}=0 \\
\frac{\partial v_{x}}{\partial t}+v_{x} \frac{\partial v_{x}}{\partial x}+v_{y} \frac{\partial v_{x}}{\partial y}-f v_{y}+g \frac{\partial h}{\partial x}+\frac{g}{2} \frac{d}{\rho} \frac{\partial \rho}{\partial x}+R v_{x}-\frac{C_{d} \rho_{a}}{d} W^{2} \sin \psi+-k\left(\frac{\partial^{2} v_{x}}{\partial x^{2}}+\frac{\partial^{2} v_{x}}{\partial y^{2}}\right)=0 \\
\frac{\partial v_{y}}{\partial t}+v_{x} \frac{\partial v_{y}}{\partial x}+v_{y} \frac{\partial v_{y}}{\partial y}+f v_{x}+g \frac{\partial h}{\partial y}+\frac{g}{2} \frac{d}{\rho} \frac{\partial \rho}{\partial y}+R v_{y} \frac{C_{d} \rho_{a}}{d} W^{2} \cos \psi-k\left(\frac{\partial^{2} v_{y}}{\partial x^{2}}+\frac{\partial^{2} v_{y}}{\partial y^{2}}\right)=0 \\
\frac{\partial(C d)}{\partial t}+\frac{\partial}{\partial x}\left(v_{x} C d\right)+\frac{\partial}{\partial y}\left(v_{y} C d\right)-\frac{\partial}{\partial x}\left(D_{x} d \frac{\partial C}{\partial x}\right)-\frac{\partial}{\partial y}\left(D_{y} d \frac{\partial C}{\partial y}\right)-q_{s g} C_{s g} d-q_{r} C_{r} d=0
\end{gathered}
$$


where $h$ is water stage [L], $d$ is water depth [L], $v_{x}$ and $v_{y}$ are vertically averaged velocities in the $x$ - and $y$-directions $\left[\mathrm{LT}^{-1}\right], q_{s g}$ is a source/sink term representing the volumetric exchange between surface water and ground water per unit area $\left[\mathrm{LT}^{-1}\right], q_{r}$ is a rainfall source term representing the volumetric rate per unit area $\left[\mathrm{LT}^{-1}\right], q_{e t}$ is an evapotranspiration sink term representing the volumetric rate per unit area $\left[\mathrm{LT}^{-1}\right], f$ is the Coriolis parameter $\left[\mathrm{T}^{-1}\right], g$ is gravitational acceleration $\left[\mathrm{LT}^{-2}\right], \rho$ is water density $\left[\mathrm{ML}^{-3}\right], R$ is the bottom-stress coefficient $\left[\mathrm{T}^{-1}\right], C_{d}$ is the wind-stress coefficient $\left[\mathrm{L}^{0}\right], \rho_{a}$ is air density $\left[\mathrm{ML}^{-3}\right], W$ is wind speed $\left[\mathrm{LT}^{-1}\right]$, $\psi$ is the angle between wind direction and the positive $y$-axis [degrees], $k$ is the horizontal momentum-exchange coefficient $\left[\mathrm{L}^{2} \mathrm{~T}^{-1}\right], C$ is solute concentration for a conservative non-reactive constituent $\left[\mathrm{ML}^{-3}\right], D_{x}$ and $D_{y}$ are the dispersion coefficients in the $x$ - and $y$-directions $\left[\mathrm{L}^{2} \mathrm{~T}^{-1}\right], C_{s g}$ is the leakage concentration between surface water and ground water $\left[\mathrm{ML}^{-3}\right]$, and $C_{r}$ is the solute concentration of rainfall. In this paper, the source concentration for rainfall and the sink concentration for evapotranspiration are both assumed to be zero, because $C$ represents salinity concentration, which is considered conservative and non-reacting. The transport equation (eq. 4) can easily be extended to represent reactive and decaying constituents. Fluid density is related to salinity, in practical salinity units (psu), using the following equation of state:

$$
\rho=\rho_{f}+\frac{\partial \rho}{\partial C} C
$$

where $\rho_{f}$ is the reference fluid density (that is, the density of freshwater) $\left[\mathrm{ML}^{-3}\right]$, and $\partial \rho / \partial C$ is the slope of a linear relation between fluid density and salinity $\left[\mathrm{L}^{0}\right]$. For salinities ranging between freshwater and typical seawater, $\partial \rho / \partial C$ has an approximate value of 0.7. The effect of temperature on fluid density is not considered here, although it could be important for some applications. For the Everglades application, seasonal temperature variations can be substantial, but spatial variations are assumed to have a negligible effect on flow. Simultaneous solutions to equations 1 through 5 result in spatial distributions for $h, C, \rho, v_{x}$, and $v_{y}$.

\section{Ground-Water Flow and Solute Transport}

Simulation of ground-water flow in an aquifer with spatially varying fluid density requires solving the three-dimensional, coupled ground-water flow and solute-transport equations. The assumption of shallow depths (used for surface-water flow) does not apply to ground water, and a full, three-dimensional solution is required to account for vertical variations in aquifer properties and flow patterns. Guo and Langevin (2002) derive a variable-density form of the fully saturated, three-dimensional ground-water flow equation in terms of $h_{f}$, which is equivalent freshwater head [L] (Lusczynski, 1961):

$$
\begin{aligned}
& \frac{\partial}{\partial x}\left[\rho K_{f, x x}\left(\frac{\partial h_{f}}{\partial x}\right)\right]+\frac{\partial}{\partial y}\left[\rho K_{f, y y}\left(\frac{\partial h_{f}}{\partial z}\right)\right]+\frac{\partial}{\partial z}\left[\rho K_{f, z z}\left(\frac{\partial h_{f}}{\partial x z}+\frac{\rho-\rho_{f}}{\rho_{f}}\right)\right]-\rho_{s g} q_{s g}+\rho_{f} q_{r}+\rho_{f} q_{e t} \\
& \quad=\rho S_{f} \frac{\partial h_{f}}{\partial t}+\theta \frac{\partial \rho}{\partial C} \frac{\partial C}{\partial t}
\end{aligned}
$$

where $K_{f, x x}, K_{f, y y}$ and $K_{f, z z}$ are equivalent freshwater hydraulic conductivities $\left[\mathrm{LT}^{-1}\right]$ in the $x$-, $y$-, and $z$-directions, $\rho_{s g}$ is the density of the leakage fluid calculated by substituting $C_{s g}$ into equation $5\left[\mathrm{ML}^{-3}\right], S_{f}$ is the specific storage in terms of equivalent freshwater head $\left[\mathrm{L}^{-1}\right]$, and $\theta$ is porosity $\left[\mathrm{L}^{0}\right]$. The governing equation for solute transport within a porous medium (Zheng and Wang, 1999) is written as:

$$
\begin{aligned}
& \frac{\partial}{\partial x}\left(\theta D_{x x} \frac{\partial C}{\partial x}+\theta D_{x y} \frac{\partial C}{\partial y}+\theta D_{x z} \frac{\partial C}{\partial z}\right)-\frac{\partial}{\partial x}\left(q_{x} C\right)+ \\
& \frac{\partial}{\partial y}\left(\theta D_{y x} \frac{\partial C}{\partial x}+\theta D_{y y} \frac{\partial C}{\partial y}+\theta D_{y z} \frac{\partial C}{\partial z}\right)-\frac{\partial}{\partial y}\left(q_{y} C\right)+ \\
& \frac{\partial}{\partial z}\left(\theta D_{z x} \frac{\partial C}{\partial x}+\theta D_{z y} \frac{\partial C}{\partial y}+\theta D_{z z} \frac{\partial C}{\partial z}\right)-\frac{\partial}{\partial z}\left(q_{z} C\right)-q_{s g} C_{s g}=\frac{\partial(\theta C)}{\partial t}
\end{aligned}
$$

where $q_{x}, q_{y}$, and $q_{z}$ are the specific discharges in the $x$-, $y$-, and $z$-directions [ $\left.\mathrm{LT}^{-1}\right]$. Equations 6 and 7 are coupled in two ways. First, the fluid density terms in equation 6 are related to solute concentrations through the equation of state (eq. 5). Second, the solute-transport equation (eq. 7) contains specific discharge terms $\left(q_{x}, q_{y}\right.$, and $\left.q_{z}\right)$ that result from a solution to the ground-water flow equation (eq. 6). 


\section{Simulation of Integrated Surface-Water/Ground-Water Flow and Salinity for a Coastal Wetland and Adjacent Estuary}

\section{Surface-Water/Ground-Water Interactions}

A variety of methods, and combinations thereof, were evaluated for calculating flow interactions between surface water and ground water, including a simple Darcy equation, modified versions of the Green-Ampt infiltration equation (Green and Ampt, 1911), and a solution to the Richard's equation (Richards, 1931). Field observations and model results confirm that unsaturated zones are rarely encountered in the Everglades coastal wetlands, but if encountered, they are thin and of short duration. Based on these observations, a simple variable-density form of Darcy's equation (Juster, 1995; Guo and Langevin, 2002) written in terms of equivalent freshwater head was programmed to calculate vertical leakage between the wetlands and aquifer. If a thin unsaturated zone develops during the simulation, leakage rates are constrained such that rates do not increase as the water table drops farther below land surface (described in the next section). The leakage flux is applied as a source/sink term in the continuity equation for surface-water flow (eq. 1) and as a boundary flux to the aquifer surface for the ground-water system. The difference in treatment is due to a two-dimensional surface-water model and a three-dimensional ground-water model. Vertical leakage is calculated using the following variable-density form of Darcy's law:

$$
q_{s g}=-K_{f, z z}\left(\frac{\partial h_{f}}{\partial z}+\frac{\rho-\rho_{f}}{\rho_{f}}\right)
$$

In this paper, solute mass transfer between systems is assumed to occur solely through advection. Thus, the solute mass flux is simply the product of leakage and the upstream solute concentration of the leakage fluid.

\section{Numerical Implementation}

To solve the coupled surface-water and ground-water equations presented in the previous section, the finite-difference programs, SWIFT2D and SEAWAT, were modified to run timesteps sequentially under the control of a master program called FTLOADDS (Flow and Transport in a Linked Overland/Aquifer Density Dependent System). The SWIFT2D two-dimensional hydrodynamic flow and solute-transport code was originally developed for bays and shallow estuaries (Leendertse and Gritton, 1971; Leendertse 1987). The code has been applied to Jamaica Bay, New York (Leendertse, 1972), to Delta Works, The Netherlands (Leendertse and others, 1981), to Tampa, Florida (Goodwin, 1987; Goodwin 1991), to Pamlico River Estuary, North Carolina (Bales and Robbins, 1995), to Charlotte Harbor, Florida (Goodwin, 1996) and to the Neuse River Estuary, North Carolina (Robbins and Bales, 1995). The SWIFT2D program was later modified by Swain and others (2004) to represent overland flow in coastal wetlands and to include the effects of spatially distributed rainfall and evapotranspiration. SWIFT2D uses a finite-difference approximation to solve the surface-water equations (eqs. 1-5). SEAWAT, a combined version of MODFLOW (McDonald and Harbaugh, 1988) and MT3DMS (Zheng and Wang, 1999), was designed to solve the three-dimensional variable-density ground-water flow and solute-transport equations (eqs. 5-7) using finite-difference methods (Guo and Bennett, 1998; Guo and Langevin, 2002; Langevin and others, 2003). Examples of SEAWAT applications include simulation of submarine ground-water discharge to a marine estuary (Langevin, 2001, 2003) and intercode comparisons (Bakker, 2003; Bakker and others, 2004).

SWIFT2D uses an alternating-direction implicit (ADI) method and a space- and time-staggered grid to solve the governing equations, such that each surface-water timestep is divided into two half timesteps-one half timestep for flow and transport in the $x$-direction and the other for the $y$-direction. In each of the two phases of the ADI method, the continuity equation and one of the components of the momentum equations are solved with local storage (and corresponding transport term of the continuity equation), local acceleration, pressure gradient, and the frictional term of the momentum equation treated implicitly. The last three terms on the left-hand side of equation 1 (the source and sink terms) are not included in the finite-difference solution, but are separately added to, or subtracted from, the cell volume. SEAWAT uses an implicit finite-difference approximation to solve the ground-water flow equation (eq. 6), and contains several alternative methods for solving the solute-transport equation (eq. 7), including implicit and explicit finite-difference methods with various weighting options and the method of characteristics.

The integrated code for SWIFT2D and SEAWAT requires cells that coincide and are identical in size. The integrated code was designed such that the domains of the two models need not be identical, provided that leakage fluxes can be neglected in areas where the two models do not overlap. Although not used for the Everglades application, this feature may prove useful for certain applications where the extension of the model domain is necessary in only one of the two systems. 


\subsection{Coupling Procedure}

Panday and Huyakorn (2004) discuss several options for coupling surface and subsurface models: (1) a "fully coupled" or "fully implicit" approach, (2) a sequentially coupled approach in which the interaction flux is applied as a boundary condition to each model, or (3) a sequentially coupled approach in which the head for one system acts as a general-head boundary for the other system. Fairbanks and others (2001) demonstrate that the fully implicit approach, in which a single set of matrix equations is formulated for both systems, is the most robust and accurate. Reported applications with the "fully coupled" approach have been limited to using a diffusion analogy or kinematic wave approximation for the overland flow system. The sequentially coupled approaches may be programmed to use an iterative coupling scheme, in which solutions are repeated for the same timestep until the change between subsequent interaction fluxes is less than a user-specified value, or a time-lagged approach. One advantage of the sequentially coupled approach (used here) is that many sub-timesteps can be used for the surface model before solving for a longer subsurface timestep (Fairbanks and others, 2001). This advantage is particularly useful for the Everglades application, where surface-water timesteps are constrained far more severely than ground-water timesteps because of rapid surface-water wave propagation speeds.

A sequentially coupled time-lagged approach was implemented to couple the surface-water and ground-water systems. The approach is mass conservative in that the exact leakage flux imposed on the surface-water system is also imposed on the groundwater system. Figure 2 shows a schematic of the coupling approach for a single ground-water stress period $(m)$, which is a time period when hydraulic stresses are assumed constant. First, surface-water flow is simulated for each sub-timestep $(n)$ by applying a leakage rate calculated with the ground-water head from the end of the previous stress period and the surface-water level at the current sub-timestep. To ensure conservation of fluid mass, individual leakage quantities for each surface sub-timestep are summed according to the following equation to calculate a time-weighted average leakage rate, $\bar{q}_{s g}^{m}$, for the stress period:

$$
\bar{q}_{s g}^{m}=\frac{\sum_{n=1}^{n s u b} \Delta t_{n} q_{s g}^{m, n}}{\sum_{n=1}^{n s u b} \Delta t}
$$

where $m$ is stress period number, $n s u b$ is the number of sub-timesteps in the stress period, and $\Delta t$ is the sub-timestep length. This average leakage rate is then applied to the ground-water model as a specified-flux boundary that remains constant for the stress period.

\section{Leakage Calculation}

The leakage flux is calculated in one of three ways, depending on the presence of standing surface water and the vertical position of the water table. For sub-timesteps with a dry surface-water cell, the leakage flux is set to zero:

For dry surface-water conditions,

$$
q_{s g}=0
$$

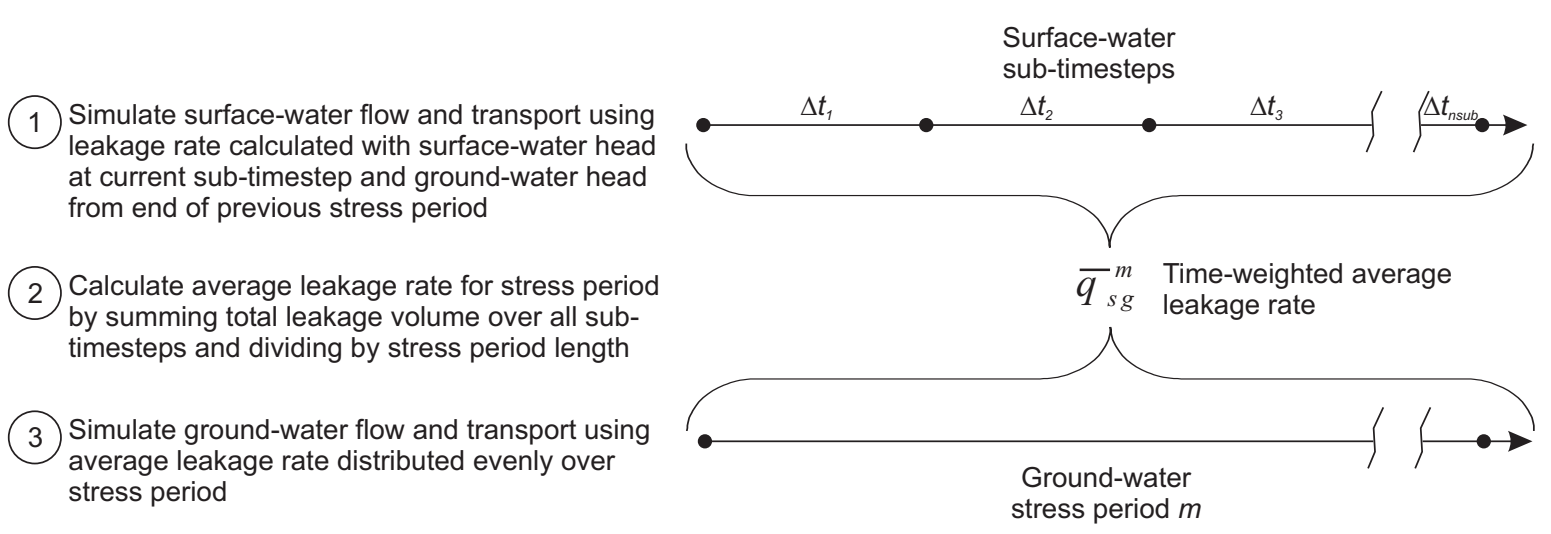

Figure 2. Relation between surface-water and ground-water timesteps. 


\section{Simulation of Integrated Surface-Water/Ground-Water Flow and Salinity for a Coastal Wetland and Adjacent Estuary}

For cells with standing surface water, the leakage formulation is based on a variable-density form of Darcy's law, where the conductance term is calculated using the mean hydraulic conductivity between land surface and the vertical center of the top aquifer layer (fig. 3). Thus, the leakage flow length is from land surface to the center of the top aquifer layer, where the equivalent freshwater head is calculated by SEAWAT. The formulation allows for the presence of a thin, hydraulically resistive layer at the land surface, which for the Everglades application, corresponds to the peat and marl unit overlying the Biscayne aquifer. Thus, for cells where the surface-water level, $h_{i, j, 0}$, is above land surface, $Z_{i, j, 0}$, and the water-table elevation, $h_{i, j, 1}$, is above the bottom of the thin layer (as shown in figure 3), the leakage flux is calculated using the following variable-density form of Darcy's law:

For $\mathrm{h}_{\mathrm{i}, \mathrm{j}, 0}>\mathrm{Z}_{\mathrm{i}, \mathrm{j}, 0}$ and $\mathrm{h}_{\mathrm{i}, \mathrm{j}, 1} \mathrm{Z}_{\mathrm{i}, \mathrm{j}, \mathrm{TL} \_ \text {BOT }}$

$$
q_{s g}=-\frac{K_{f, i, j, 1 / 2}}{0.5 \Delta Z_{i, j, 1}}\left[h_{f, i, j, 0}-h_{f, i, j, 1}+\frac{\rho_{i, j, 1 / 2}-\rho_{f}}{\rho_{f}}\left(Z_{i, j, 0}-Z_{i, j, 1}\right)\right]
$$

where $Z_{i, j, T L \_B O T}$ is the elevation of the thin layer bottom [L], $K_{f, i, j, 1 / 2}$ is the thickness-weighted harmonic mean average of equivalent freshwater hydraulic conductivity between land surface and the center of aquifer layer $1\left[\mathrm{LT}^{-1}\right], \Delta Z_{i, j, 1}$ is the layer 1 cell thickness, $h_{f, i, j, 0}$ is the equivalent freshwater head [L] of the surface water (layer 0 ) evaluated at land surface, $h_{f, i, j, 1}$ is the equivalent freshwater head $[\mathrm{L}]$ at the vertical center of layer $1, \rho_{i, j, 1 / 2}$ is the average surface- and ground-water fluid density $\left[\mathrm{ML}^{-3}\right]$, and $Z_{i, j, 1}$ is the center elevation $[\mathrm{L}]$ for layer 1.

Figure 3. Diagram of a surface-water cell and an uppermost aquifer cell. Piezometers are used to demonstrate the concept of equivalent freshwater head and the reference elevations for calculating equivalent freshwater head.

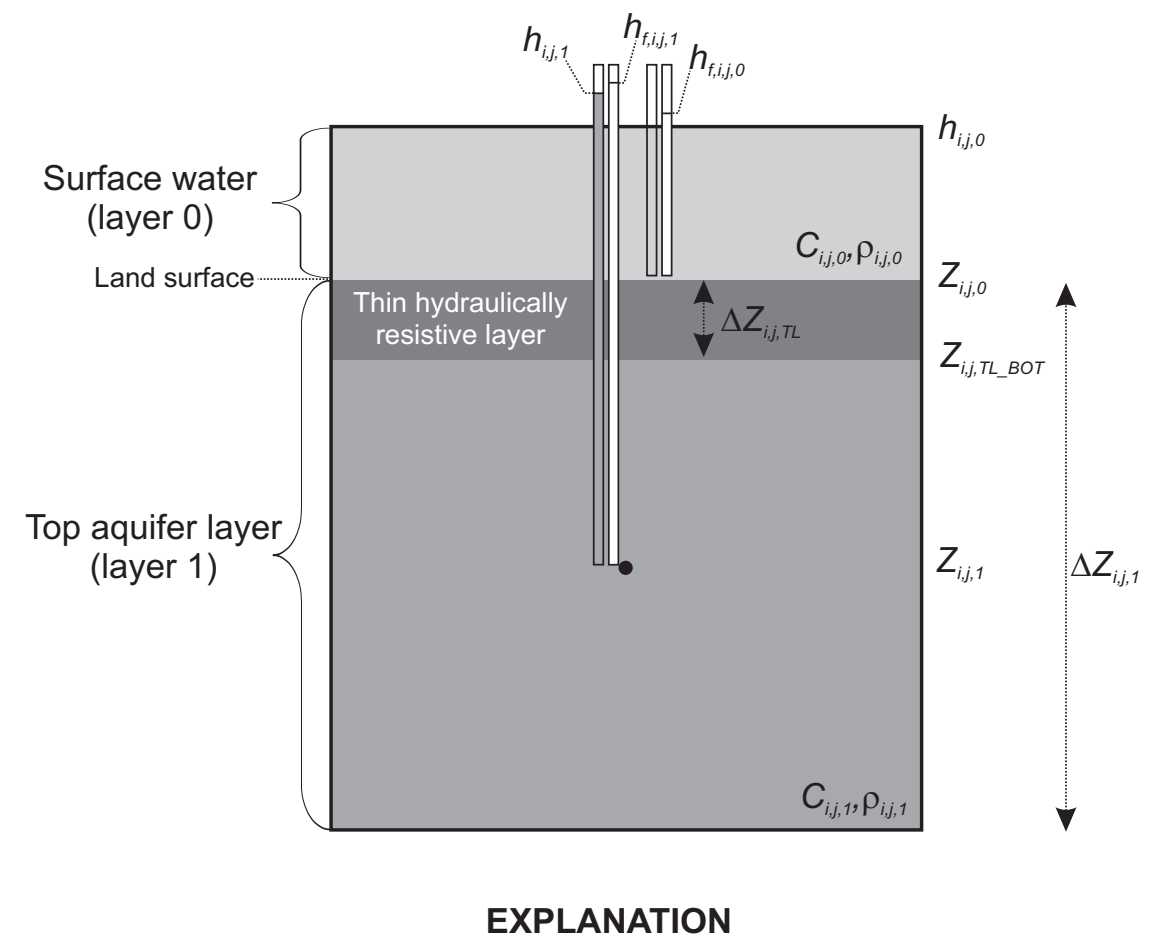

$h_{i, j}$ is the head in a piezometer open at the center of aquifer layer 1

$h_{t i, j, 1}$ is the equivalent freshwater head in a piezometer open at the center of aquifer layer 1

$h_{i, j, 0}$ is the elevation of the water surface

$h_{f i, j, 0}$ is the equivalent freshwater head in a piezometer open at land surface

$C_{i, j, 0}$ is the solute concentration of the surface water

$\rho_{i, j, 0}$ is the density of the surface water

$C_{i, j, 1}$ is the solute concentration of the ground water in aquifer layer 1

$\rho_{i, j, 1}$ is the density of the ground water in aquifer layer 1

$Z_{i, j, 0}$ is the elevation of land surface

$Z_{i, j, T_{-} B O T}$ is the elevation at the base of the thin layer

$\Delta Z_{i, j, T L}$ is the thickness of the thin layer

$Z_{i, j, 1}$ is the center elevation of aquifer layer 1

$\Delta Z_{i, j, 1}$ is the thickness of aquifer layer 1 
Although rare for the Everglades application, a thin unsaturated zone can develop if the surface-water layer is rapidly flooded while the water table remains below the bottom of the thin hydraulically resistive layer. If these conditions occur in the model, equation 10 is no longer valid, and it is assumed that the entire head loss between land surface and the center of the cell occurs across the thin layer. With this assumption and the assumption that the pressure at the bottom of the thin layer is atmospheric, the following equation is used to approximate the flux through the thin unsaturated zone:

For $\mathrm{h}_{\mathrm{i}, \mathrm{j}, 0}>\mathrm{Z}_{\mathrm{i}, \mathrm{j}, 0}$ and $\mathrm{h}_{\mathrm{i}, \mathrm{j}, 1}<\mathrm{Z}_{\mathrm{i}, \mathrm{j}, \mathrm{TL} \_ \text {BOT, }}$

$$
q_{s g}+-\frac{K_{f, i, j, T L}}{\Delta Z_{i, j, T L}}\left[h_{f, i, j, 0}-Z_{i, j, T L-B O T}+\frac{\rho_{i, j, 0}-\rho_{f}}{\rho_{f}} \Delta Z_{i, j, T L}\right]
$$

where $K_{f, i, j, T L}$ is the vertical equivalent freshwater hydraulic conductivity of the thin layer [ $\left.\mathrm{LT}^{-1}\right], \Delta Z_{i, j, T L}$ is the thickness of the thin layer [L], and $\rho_{i, j, 0}$ is the density of the surface water $\left[\mathrm{ML}^{-3}\right]$. This approximation for the flux through the unsaturated zone is based on the approach used by MODFLOW (McDonald and Harbaugh, 1988) and SEAWAT (Guo and Langevin, 2002) for the River package. A more sophisticated approach, such as one based on a modified Green-Ampt formulation may be required if future applications result in ponded surface water overlying a relatively thick unsaturated zone.

\subsection{Surface/Subsurface Solute Exchange}

A mass-conservative approach was designed to allow advective transport between the wetland and underlying aquifer. Calculation of the advective mass flux is straightforward for most stress periods in which the advective flux is either up or down for the entire period. If leakage is downward, the advective mass flux is the product of the leakage rate and the surface-water solute concentration. Likewise, for upward leakage, the advective mass flux is the product of the leakage rate and the ground-water solute concentration.

Concentration changes that result from advective transport between the wetland and aquifer are calculated for each subtimestep in SWIFT2D. To account for advective leakage transport in the ground-water model, the total solute mass added to, and subtracted from, the surface-water cell is summed in SWIFT2D for each stress period. This total mass transferred is then divided by the total leakage volume for that stress period to calculate an effective leakage concentration. Thus, the volumetric leakage rate applied to SEAWAT has an associated effective concentration that results in the conservation of mass between the two systems. If multiple reversals of leakage direction occur during a single stress period, the effective concentration can be very small or even negative. If a highly saline ground-water system is overlain by a fresh surface-water system and leakage reverses direction multiple times, then the net salt transfer will be upward even if the net leakage is downward. In this case, the effective concentration will be negative indicating that the net salt flux is in the opposite direction of the net volume flux.

\subsection{Spatially Distributed Rainfall and Evapotranspiration}

The original SWIFT2D program was modified to include spatially distributed rainfall and evapotranspiration (Swain and others, 2004). For conditions with standing surface water, rainfall is applied to the surface-water layer with a solute concentration of zero. If a surface-water cell is dry, the rainfall volume is applied directly and instantaneously to the water table in layer 1 of the ground-water model. The same approach is used to determine where the evapotranspiration flux is applied. In the current Everglades application, however, the evapotranspiration flux is calculated by the model during the simulation using a modified PriestlyTaylor approximation to the physics-based Penman-Monteith model as described by German (2000a; 2000b) and Swain and others (2004). Evapotranspiration rates are calculated as a function of solar radiation and water depth. Two sets of coefficients were estimated through linear regression and used in the Priestly-Taylor approximation. One set was calculated for conditions with standing water; the other was calculated for dry surface-water conditions when the water table was below land surface. For conditions with standing water, the entire evapotranspiration flux is withdrawn from surface water, rather than withdrawing evaporation from surface water and transpiration from ground water.

\subsection{Rewetting}

In the present integrated code, surface-water and ground-water cells are allowed to dry and rewet. The original versions of SWIFT2D and SEAWAT both have options for cells to rewet from the four surrounding nodes, and in the case of SEAWAT, from an underlying node. Rewetting in SEAWAT is a simple extension of the procedure implemented in MODFLOW (McDonald and others, 1992). In the integrated program, a modification was made to SWIFT2D to allow surface-water cells to rewet from the underlying ground-water cell if the water table rises above land surface. If a surface-water cell is dry, then SWIFT2D compares 


\section{Simulation of Integrated Surface-Water/Ground-Water Flow and Salinity for a Coastal Wetland and Adjacent Estuary}

surrounding stages and height of the water table with land-surface elevation. This comparison is performed for a sub-timestep interval provided by the user. If a surrounding stage or water-table elevation is above land surface, the cell is reactivated and included in the computational domain for the subsequent sub-timestep.

\section{Application of Integrated Model to the Southern Florida Everglades}

The integrated model was applied to the southern Everglades and northeastern Florida Bay (fig. 4) to evaluate the dominant hydrologic processes, including surface-water and ground-water interactions, and to synthesize a wide range of hydrologic data collected for the area. The specific objective of the model application was to develop a numerical tool that could be used to quantify freshwater discharges to northeastern Florida Bay, predict temporal and spatial variations in coastal salinity patterns, and represent wetland hydroperiods. Presently, the numerical tool is being used to evaluate the effects of the Comprehensive Everglades Restoration Plan (CERP) on future hydrologic conditions (heads, flows, and salinities) in the coastal wetlands and adjacent Florida Bay estuary. The principal purpose of CERP is to restore the southern Florida ecosystem, which includes the Everglades (http:// www.evergladesplan.org).

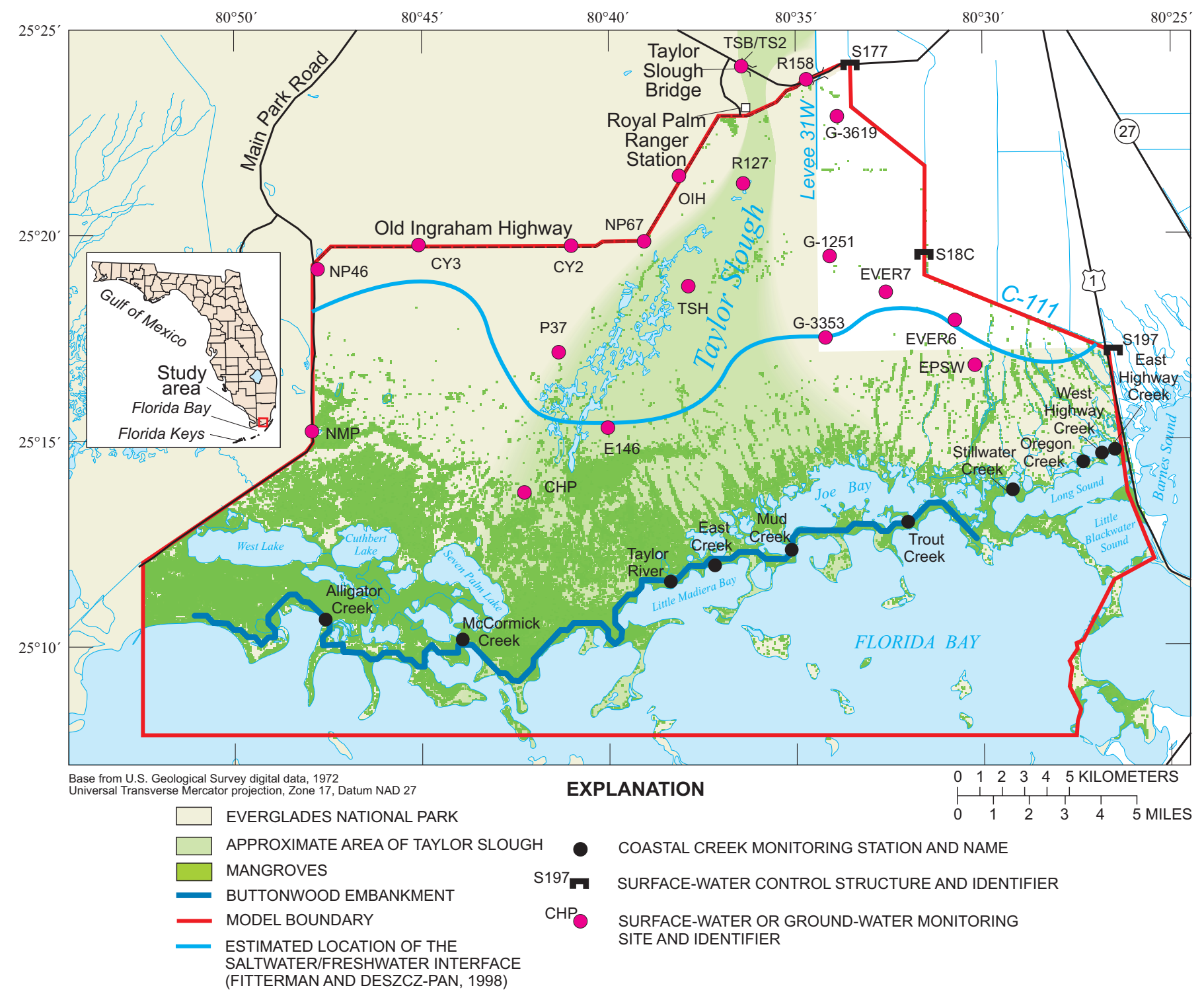

Figure 4. Study area including location of Taylor Slough, Florida Bay, monitoring stations, and model boundary. 
The U.S. Geological Survey began modeling Taylor Slough hydrology in 1995 with the development of a hydrodynamic surface-water flow and solute-transport model, as described by Swain and others (2004). Information relevant to the application of the present integrated code is briefly summarized here. The surface-water model by Swain and others (2004) simulated the 1-year period from August 1996 to July 1997. As treatment of surface-water and ground-water exchanges was not included in the early model, the lack of a ground-water component was a limitation, considering the documented importance of surface-water and ground-water exchanges in southern Florida (for example, Merritt, 1996a; Swain and others, 1996). Subsequently, the FTLOADDS program was designed and a SEAWAT ground-water model was developed for the study area. The integrated simulation, described herein, was extended to 7 years to represent the period from January 1996 to December 2002. There are a total of 2,542 one-day ground-water stress periods, with each day divided into 7.5-minute surface-water sub-timesteps. The model also includes a 15-day "warm-up period" in which only the surface-water system is simulated. The initial condition for the simulation is a fresh, flat pool at an elevation of $0.78 \mathrm{~m}$ above the North American Vertical Datum of 1988 (NAVD 88). Leakage and solute mass transfer to or from the surface-water system is included during the warm-up period using initial ground-water heads and salinities that remain constant during the 15-day period. Initial ground-water heads and salinities were set using the results from a preliminary 7-year simulation that had been rerun seven times until the model reached dynamic equilibrium.

\subsection{Description of Study Area}

The focus of the model application is a $900-\mathrm{km}^{2}$ area of southeastern Everglades National Park that includes northeastern Florida Bay (fig. 4). The study area encompasses Taylor Slough, which is the smaller of two main Everglades sloughs in southern Florida. Rainfall is a dominant source of freshwater for the study area, which receives an average of about $140 \mathrm{~cm} / \mathrm{yr}$. Inflows also occur by means of a water-management system that controls water levels in southern Florida to prevent flooding. A pump structure (S332; not shown) is used to transfer water from the Levee 31W (L-31W) canal into the wetlands just north of Taylor Slough Bridge (fig. 4). A portion of this water then flows beneath Taylor Slough Bridge into the main part of Taylor Slough, which extends south to Little Madeira Bay and Florida Bay and east toward Joe Bay. The L-31W canal, which extends southward from the northern model boundary, is another contributor of freshwater to the coastal wetlands and usually flows only during flood control operations. Inflows are also common from the C-111 canal between control structures S18C and S197. A continuous levee once existed on the south side of C-111 between S18C and S197. In the 1970's, notches were cut through the levee to allow surface water from C-111 to flow into the coastal wetlands. In 1998, much of the remaining levee was degraded to increase inflows into the wetland area south of S18C. On the west side of the study area, culverts beneath the Main Park Road allow surface water to exchange with the wetlands to the west, but flow measurements indicate the exchanges are minimal (Tillis, 2001; Stewart and others, 2002)

A principal hydrologic feature in the study area is the Buttonwood Embankment—a nearly continuous ridge along the Florida Bay coastline. This ridge is observed to be about $0.3 \mathrm{~m}$ higher than the surrounding marsh, and was formed either by the buildup of organic detritus from the stands of mangrove forest or by sediment deposition from Florida Bay during periodic hurricanes and tropical storms (Holmes and others, 2000). The ridge itself forms a partial low-crowned barrier and obstructs direct overland flow from the coastal wetlands into northeastern Florida Bay at most times. Hydraulic connection between the coastal wetlands and northeastern Florida Bay occurs through coastal creeks that have incised the Buttonwood Embankment. Overtopping is infrequent and is typically caused by northward moving storms or hurricanes that force brackish Florida Bay water over the embankment and into the coastal wetlands (Hittle, 2000).

In 1995, the U.S. Geological Survey began collecting continuous (15-minute interval) discharge, stage, and salinity data at the mouths of coastal creeks (Hittle and others, 2001). These field data quantify exchange rates between the coastal wetlands and northeastern Florida Bay and provide insight about the hydrologic processes driving the exchanges. The field data reveal the following general patterns and trends (Hittle, 2000): (1) the average annual net discharge to Florida Bay through the five measured coastal creeks (McCormick, Mud, Trout, Taylor River, and West Highway) is $3.2 \times 10^{8} \mathrm{~m}^{3} / \mathrm{yr}$, with about 80 percent of the discharge occurring during the summer months from May to October; (2) most of the discharge (60 percent) to northeastern Florida Bay occurs through Trout Creek; (3) wind variations seem to cause flow reversals, forcing brackish Florida Bay waters up into the bays and coastal wetlands; and (4) the interconnected mud banks of Florida Bay and the Florida Keys substantially dampen the tidal signature in the northeastern part of the bay.

Field studies of surface-water and ground-water interactions within the Taylor Slough area are reported by Harvey and others (2000a, 2000b) and Price (2001). Using a chloride dilution method, Harvey and others (2000a) indicated that: (1) upward groundwater flow in November 1997 may have been as large as $3 \mathrm{~cm} / \mathrm{d}$ in the area near NP67 and TSH (fig. 4), (2) the high water levels on the northwestern side of Old Ingraham Highway are probably driving ground-water flow into the western part of Taylor Slough, and (3) upward ground-water flow within the slough itself is about $0.06 \mathrm{~cm} / \mathrm{d}$ for the period between September 1997 and September 1999. Using a variety of geochemical tracers, Price (2001) estimated leakage rates that ranged over 4 orders of magnitude.

Salinity patterns in northeastern Florida Bay are highly influenced by freshwater discharges from the coastal wetlands (Hittle, 2000; Nuttle and others, 2000). Flows from coastal creeks appear to be the dominant source of freshwater for northeastern Florida 
Bay, although some scientists have suggested that overtopping of the Buttonwood Embankment and ground water are important contributors. Substantial freshwater inputs into Florida Bay from shallow ground water seem unlikely because recent helicopter electromagnetic surveys revealed that shallow saline ground water extends at least $7 \mathrm{~km}$ inland (fig. 4; Fitterman and Deszcz-Pan, 1998). Corbett and others (1999) used geochemical tracers to identify submarine ground-water discharge patterns in Florida Bay and discovered what appeared to be higher discharge values near the Florida Keys than just south of the Buttonwood Embankment. They also reported that a seepage meter placed in northern Florida Bay recorded leakage rates in excess of $1 \mathrm{~cm} / \mathrm{d}$.

\subsection{Model Design}

Application of the integrated model to the southern Everglades and northeastern Florida Bay required a wide variety of input data for both the surface-water and ground-water systems. Fortunately, the study area has been the focus of concentrated hydrologic investigations. Many of these investigations were initiated primarily to collect data for the integrated model. Brief descriptions are provided here for many of the important hydrologic input parameters, such as land-surface elevation, evapotranspiration, and aquifer hydraulic conductivity.

The finite-difference model grid used for the Everglades application consists of 98 east-west rows and 148 north-south columns. Model cells are square and measure $305 \mathrm{~m}$ per side. The area of the model that corresponds to the coastal wetlands (the active model area north of the Buttonwood Embankment) is about $6.2 \times 10^{8} \mathrm{~m}^{2}$. Florida Bay comprises about $2.8 \times 10^{8} \mathrm{~m}^{2}$ of the model area. Land-surface elevations were calculated for each cell (fig. 5) by interpolating values from a helicopter global
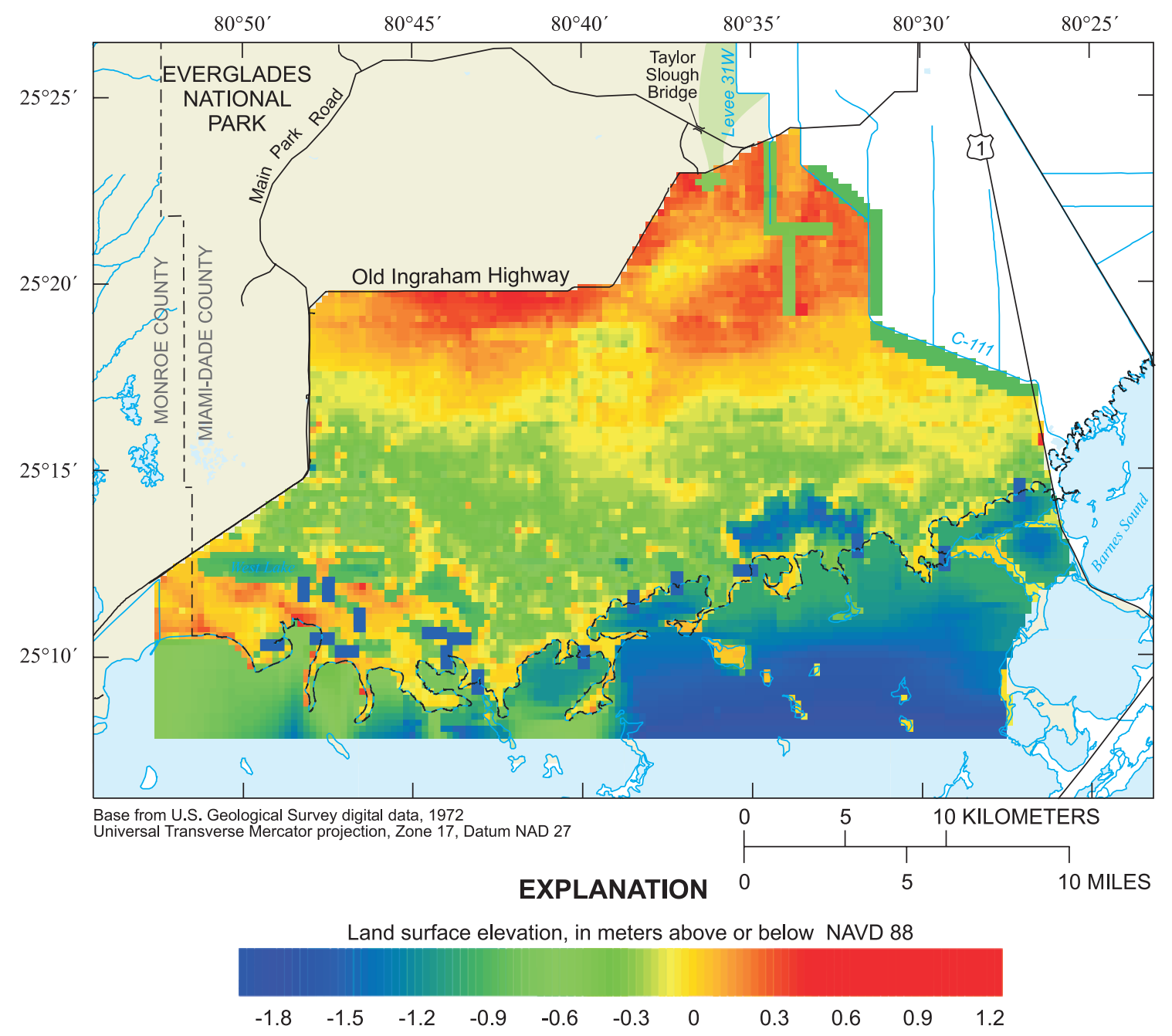

Figure 5. Grid of land-surface elevation, relative to the North American Vertical Datum of 1988 (NAVD 88), as used in the numerical model. 
positioning system (GPS) survey with 400-m spacing between measurements (Desmond, 2003). Data from National Oceanic and Atmospheric Administration (NOAA) nautical charts and from Hansen and Dewitt (2000) were used to assign bathymetry for Florida Bay and its subembayments. The Buttonwood Embankment was included in the model using the barrier feature in SWIFT2D with a specified sill height of $0.3 \mathrm{~m}$ above land surface. The three-dimensional ground-water model has 10 layers. The top layer extends from land surface to an elevation of $3.2 \mathrm{~m}$ below NAVD 88. The remaining layers are uniform in volume and have a constant thickness of $3.2 \mathrm{~m}$. The ground-water model extends from land surface to the base of the Biscayne aquifer, as defined by Fish and Stewart (1991) and revised by Fitterman and others (1999). The lower part of the surficial aquifer system, as described by Jarosewich and Wagner (1985) and Fish and Stewart (1991), is not included in the model. Within the study area, the base of the Biscayne aquifer thickens to the east. Ground-water model cells are inactive if the vertical center of the model cell is located beneath the base of the Biscayne aquifer. This approach treats the base of the Biscayne aquifer as a no-flow boundary-an approach commonly used in southern Florida (Merritt, 1996a, 1996b; Swain and others, 1996; Langevin, 2001) and justified by the sharp contrast in permeabilities.

Boundary conditions for the surface-water model were specified for the model perimeter based on the presence of roads, canals, culverts, islands, and an estimated sufficient offshore distance from the southern Florida coastline (fig. 6). The type of boundary used for each segment in figure 6 is listed in table 1 . Boundary levels and fluxes were assigned based on field data using the highest temporal frequency available. Two different types of boundaries were used for the ground-water model. North of the Florida Bay coastline, general-head boundaries were applied to each layer of the ground-water model based on interpolated head values from nearby surface-water and ground-water monitoring sites for each day of the simulation period. Salinity values assigned to the general-head boundaries in all layers were estimated from the airborne geophysical survey (Fitterman and Deszcz-Pan, 1998). South of the Florida Bay coastline (corresponding to SW4, SW5, and SW6 in fig. 6), a no-flow boundary was imposed on the ground-water model. A general-head boundary was originally used for the southern ground-water boundary, but field data were

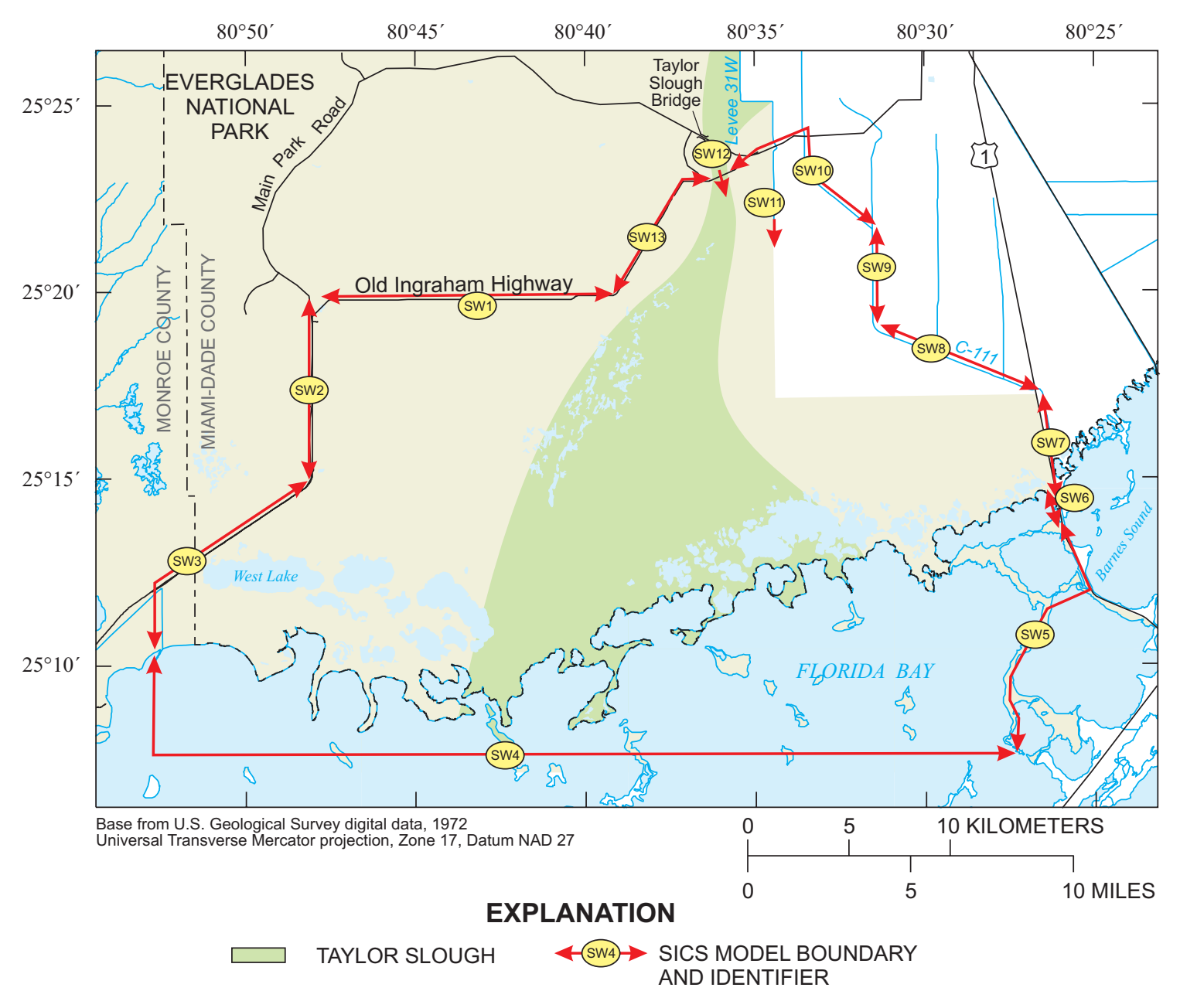

Figure 6. Model grid and index numbers for model boundaries. 


\section{Simulation of Integrated Surface-Water/Ground-Water Flow and Salinity for a Coastal Wetland and Adjacent Estuary}

not available for assignment of boundary heads and concentrations. Thus a no-flow condition was assigned based on the assumption that the boundary is far south (about 1 to $10 \mathrm{~km}$ ) of the area where ground-water discharge might occur. Simulated leakage maps confirmed this assumption.

Table 1. Description of boundary conditions for the surface-water model.

[Locations of model boundaries are in figure 6. D, specified discharge boundary; NF, no-flow boundary; WL, specified water-level boundary]

\begin{tabular}{|c|l|c|}
\hline $\begin{array}{c}\text { Identifying } \\
\text { Number }\end{array}$ & \multicolumn{1}{|c|}{ Description } & $\begin{array}{c}\text { Boundary } \\
\text { Type }\end{array}$ \\
\hline 1 & Old Ingraham Highway (north) & WL \\
\hline 2 & Main Park Road (west) & WL \\
\hline 3 & Main Park Road (southwest) & NF \\
\hline 4 & Florida Bay & WL \\
\hline 5 & Florida Bay islands & NF \\
\hline 6 & US-1 culverts & WL \\
\hline 7 & C-111 tidal canal & NF \\
\hline 8 & C-111 (S18C-S197) & D \\
\hline 9 & C-111 (north of S18C) & WL \\
\hline 10 & C-111/Main Park Road & NF \\
\hline 11 & L-31W & D \\
\hline 12 & Taylor Slough inflow & NF \\
\hline 13 & Old Ingraham Highway (northeast) & \\
\hline
\end{tabular}

Rainfall and evapotranspiration are the primary sources and sinks within the model domain. Rainfall data with recorded intervals as short as 15 minutes were spatially interpolated (kriged) for each model cell and time interpolated for each surface-water sub-timestep. Evapotranspiration was included in the model using a modified form of the Priestly Taylor approximation to the physics-based Penman-Monteith equation. Site-specific evapotranspiration data from a study by German (1999) were used to calculate coefficients within the Priestly-Taylor approximation such that evapotranspiration rates are a function of water depth and solar radiation. The dependency on water depth is unusual, but appears to be related to sheltering by vegetation and submergence of vegetation (German, 1999). Separate coefficients were determined for periods when water levels were below land surface. Swain and others (2004) provide a detailed description for the methods used to assign rainfall and evapotranspiration to the model.

The surface-water simulation is controlled by spatially varying parameters that represent relevant processes. This includes defining the frictional resistance to flow, wind friction factor and sheltering coefficient, and dispersion coefficient. The frictional resistance to flow is expressed with Manning's coefficients. Because of the importance of this term, field and laboratory research was performed to determine the effective frictional resistance to water flow through differing Everglades vegetation types (Lee and others, 1999). Extensive hydraulic measurements (velocity, depth, hydraulic gradient, and so forth) were made in a laboratory flume containing transplanted marsh vegetation. Field measurements of velocity, depth, and vegetation type and density were also made in conjunction with point measurements of the hydraulic gradient using a portable pipe manometer at many locations in the study area (Lee and others, 2000). Results of these studies indicate high Manning's $n$ values and relatively small variations between vegetation types. Values of Manning's $n$ vary spatially and range from 0.38 to $0.46 \mathrm{~s} / \mathrm{m}^{1 / 3}$ (Swain and others, 2004). Open-water areas are assigned a nominal value of $0.02 \mathrm{~s} / \mathrm{m}^{1 / 3}$. Frictional resistance values for the coastal creeks were determined by calibration and from field measurements at two monitoring stations on Taylor River (fig. 4). The measured discharge and water-level differences between the original station and the upstream station were used to determine $n$ from Manning's equation. The computed Manning's $n$ for each day was averaged for the period and yielded a mean Manning's $n$ value of $0.121 \mathrm{~s} / \mathrm{m}^{1 / 3}$ (Swain and others, 2004). The calibrated values of Manning's $n$ for the coastal creeks ranged from 0.058 to $0.152 \mathrm{~s} / \mathrm{m}^{1 / 3}$. The coefficient for the wind-friction term that related the wind velocity squared to the rate of momentum change in the water flow has a specified value of about $1.2 \times 10^{-3}$ for winds less than $36 \mathrm{~m} / \mathrm{s}$ (Large and Pond, 1981). This coefficient is uniform for the entire study area. A wind-sheltering term also is applied to account for the effects of emergent vegetation. Estimated values for this wind-sheltering term range from 0.1 to 0.5 (Reid and Whitaker, 1976); a value of 0.33 is used in the model. Jenter and Duff (1999) suggest that the values estimated by Reid and Whitaker (1976) are reasonable for the Everglades coastal wetlands. The magnitude of the dispersion coefficient for surface water is scale dependent, increasing with the size of the water body. The effective dispersion coefficient is on the order of $1-10 \mathrm{~m}^{2} / \mathrm{s}$ in open channels, and 2 orders of magnitude greater in estuaries (Fischer and others, 1979). In the application of the dispersion coefficient in a numerical model, the length scale of importance is the cell size. Therefore, the dispersion coefficient was calibrated by matching salinity values at the coastal creek measurement stations.

Application of Darcy's law to calculate leakage rates (eq. 9) required an assignment of aquifer properties to the upper half of layer 1 of the ground-water model. The current program reads the thickness and vertical hydraulic conductivity of the thin layer and the vertical hydraulic conductivity of the part of the aquifer between the base of the thin layer and the vertical center of model layer 1. Peat thickness was measured at 74 locations within Taylor Slough by pushing a steel rod through the peat to the limestone surface (Harvey and others, 2000b). Reported thickness values range between 0.3 and $2.5 \mathrm{~m}$ with an average value of $1.1 \mathrm{~m}$. Harvey and others (2000b) also measured peat hydraulic conductivity by performing bail tests at seven shallow piezometer sites. Reported hydraulic conductivity values from that study are $0.09,0.2,0.2,0.3,0.4,0.5$, and $1.3 \mathrm{~m} / \mathrm{d}$. For Florida Bay, leakage coefficients were assigned based on mapped bottom types (Prager and Halley, 1997). For hard-bottom areas such as Joe Bay, a vertical 
aquifer hydraulic conductivity value of $0.75 \mathrm{~m} / \mathrm{d}$ was used. All other bottom types in Florida Bay were assumed to have a 1-m thick sediment layer with a vertical hydraulic conductivity value of $0.1 \mathrm{~m} / \mathrm{d}$. The remaining part of the Biscayne aquifer was assumed to be isotropic and homogeneous with vertical and horizontal hydraulic conductivity values of 0.75 and 5,000 m/d, respectively. These values, which were determined through calibration, compare closely with values used in other numerical models of the area (Merritt, 1996a, 1996b; Swain and others, 1996; Langevin, 2001).

Limited data exist on the dispersive properties of the Biscayne aquifer. Merritt (1996b) developed a numerical model to simulate a chloride plume that resulted from a flowing artesian well open to the brackish Floridan aquifer. The simulated plume covered a $3 \times 10^{8} \mathrm{~m}^{2}$ area, which is similar in scale to the present study $\left(9 \times 10^{8} \mathrm{~m}^{2}\right)$. Merritt (1996b) assigned a porosity value of 0.2 based on specific yield estimates for the porous limestone aquifer, and through calibration, estimated values of 76 and $0.03 \mathrm{~m}$ for longitudinal and transverse dispersivity, respectively. Based on the relatively low value for transverse dispersivity, Merritt (1996b) concluded that the transverse dispersion simulated by the model was caused by seasonal variations in flow velocity and direction, rather than by mechanical dispersion. For the present simulation, hydrodynamic dispersion within the ground-water model was not active during the integrated simulations. Instead, it was assumed that numerical dispersion resulting from the solution to the transport equation was similar in magnitude to actual dispersion. This assumption was supported by simulated positions of the freshwater/saltwater interface in the Biscayne aquifer that matched observed positions. As additional data on the interface position, movement, and width become available, the model may be refined to include mechanical dispersion.

Table 2. Calibration statistics for daily average coastal creek discharges, surface-water stage or ground-water head, and coastal creek salinities.

[Mean errors were calculated by subtracting measured values from simulated values. Station locations are in figure 4. ME, mean error; MAE, mean absolute error; RMSE, root mean square error; Count, number of data points used to calculate statistics; $\mathrm{m}^{3} / \mathrm{s}$, cubic meters per second; psu, practical salinity units].

\begin{tabular}{|c|c|c|c|c|}
\hline Station & $\mathrm{ME}$ & MAE & RMSE & Count \\
\hline \multicolumn{5}{|c|}{ Discharge $\left(\mathrm{m}^{3} / \mathrm{s}\right)$} \\
\hline McCormick & 0.20 & 1.56 & 2.04 & 2510 \\
\hline Mud & 0.39 & 1.86 & 3.86 & 2530 \\
\hline Trout & -1.78 & 5.01 & 7.06 & 2526 \\
\hline Taylor River & -0.23 & 1.21 & 2.90 & 2554 \\
\hline West Highway & -0.30 & 1.10 & 1.65 & 2479 \\
\hline \multicolumn{5}{|c|}{ Stage/Head (m) } \\
\hline NMP & 0.02 & 0.02 & 0.02 & 2290 \\
\hline CY3 & -0.07 & 0.07 & 0.07 & 2275 \\
\hline NP46 & 0.00 & 0.06 & 0.09 & 2475 \\
\hline NP67 & 0.01 & 0.06 & 0.08 & 2493 \\
\hline CY2 & -0.03 & 0.04 & 0.05 & 2222 \\
\hline TSH & 0.00 & 0.06 & 0.08 & 2527 \\
\hline E146 & 0.05 & 0.06 & 0.09 & 2477 \\
\hline $\mathrm{CHP}$ & -0.02 & 0.06 & 0.08 & 2473 \\
\hline EPSW & 0.08 & 0.09 & 0.10 & 2461 \\
\hline EVER 6 & -0.04 & 0.06 & 0.07 & 2394 \\
\hline EVER 7 & -0.04 & 0.05 & 0.07 & 2444 \\
\hline R127 & 0.02 & 0.07 & 0.10 & 2494 \\
\hline P37 & 0.00 & 0.05 & 0.07 & 2465 \\
\hline G-3619 & -0.04 & 0.09 & 0.12 & 2438 \\
\hline G-3353 & 0.14 & 0.15 & 0.17 & 2451 \\
\hline G-1251 & 0.04 & 0.08 & 0.10 & 2034 \\
\hline \multicolumn{5}{|c|}{ Salinity (psu) } \\
\hline McCormick & 2.76 & 7.14 & 9.43 & 2508 \\
\hline Mud & 2.10 & 3.95 & 5.08 & 2421 \\
\hline Trout & 2.33 & 4.86 & 6.45 & 2529 \\
\hline Taylor River & 4.95 & 6.35 & 7.70 & 2515 \\
\hline West Highway & -1.43 & 4.60 & 5.57 & 2512 \\
\hline
\end{tabular}

\subsection{Model Calibration and Analysis of Simulation Results}

Computer runtimes in excess of 30 hours (on a Pentium IV processor running at 1.7 gigahertz) for the 7-year simulation period prohibited use of formalized parameter estimation techniques. Instead, calibration was achieved by judicious adjustment of the input parameters that seemed to have the largest uncertainty range and the largest effect on simulation results. Calibration statistics for coastal creek discharges, wetland stages, and creek salinities are reported in table 2 . In addition to the model results given in table 2 , other model results were also compared with field data. For example, the simulated aquifer salinities were carefully evaluated to ensure the model adequately matched the results from an airborne electromagnetic survey (Fitterman and Deszcz-Pan, 1998).

A water budget was prepared from model results for the coastal wetland part of the model domain, north of the Florida Bay coastline (fig. 7 and table 3). The water budget is for surface water and does not include lateral ground-water flows or evapotranspiration directly from the water table, which is about $45 \mathrm{~cm}$. Water budget components are given as annual average values for individual years (table 3) and for the 7-year simulation period (fig. 7 and table 3). Coastal creek discharges, and other discharge values, were divided by the wetland area $\left(6.2 \times 10^{8} \mathrm{~m}^{2}\right)$ to give length units that can be compared directly with rainfall and evapotranspiration. 


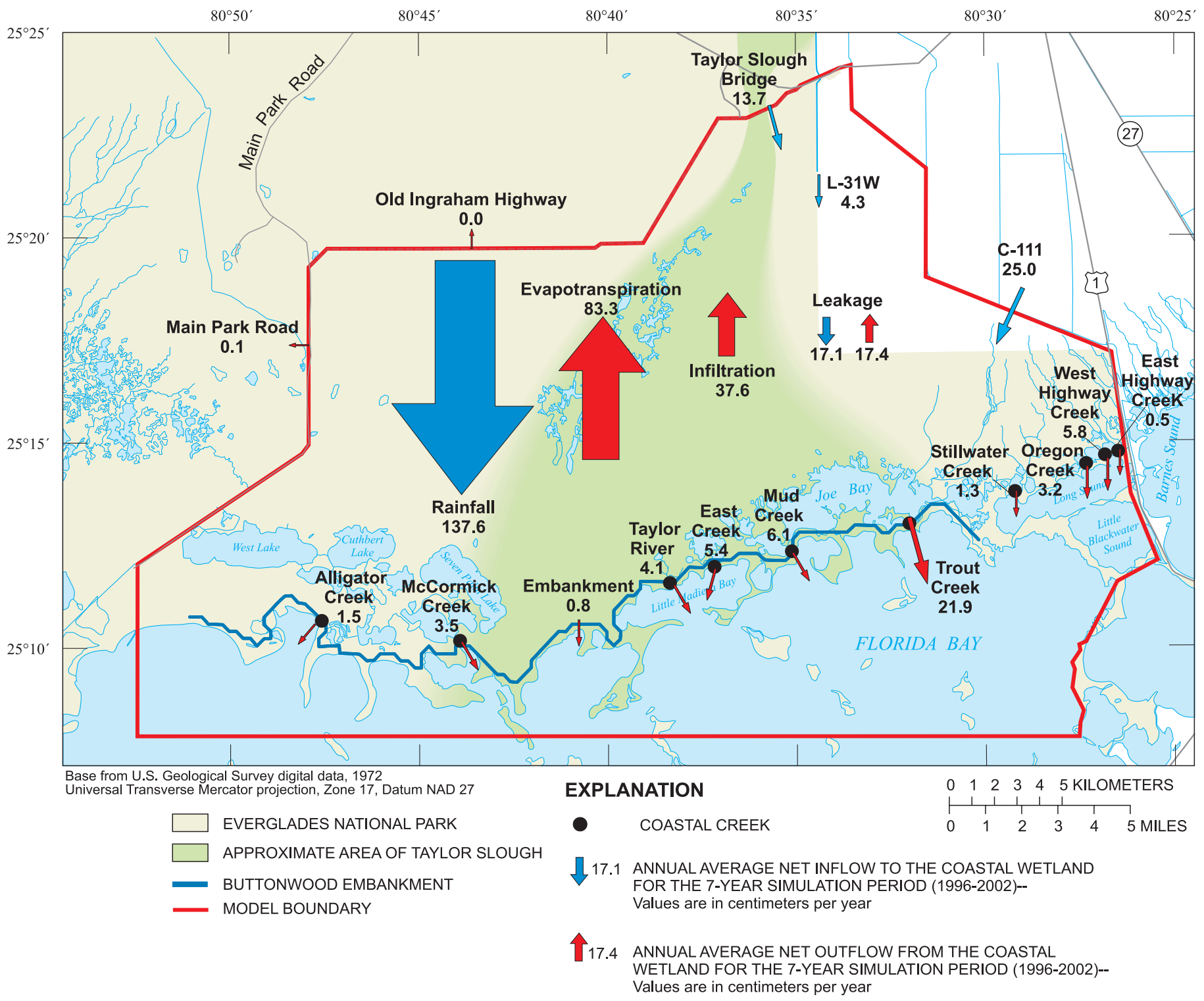

Figure 7. Annual average surface-water budget for the coastal wetland for the 7-year simulation period (1996-2002). 
Table 3. Simulated surface-water budget for the coastal wetland.

[Values are expressed in centimeters as inflows or outflows to the wetland. Discrepancies between total inflows and outflows are due to changes in storage and model error.]

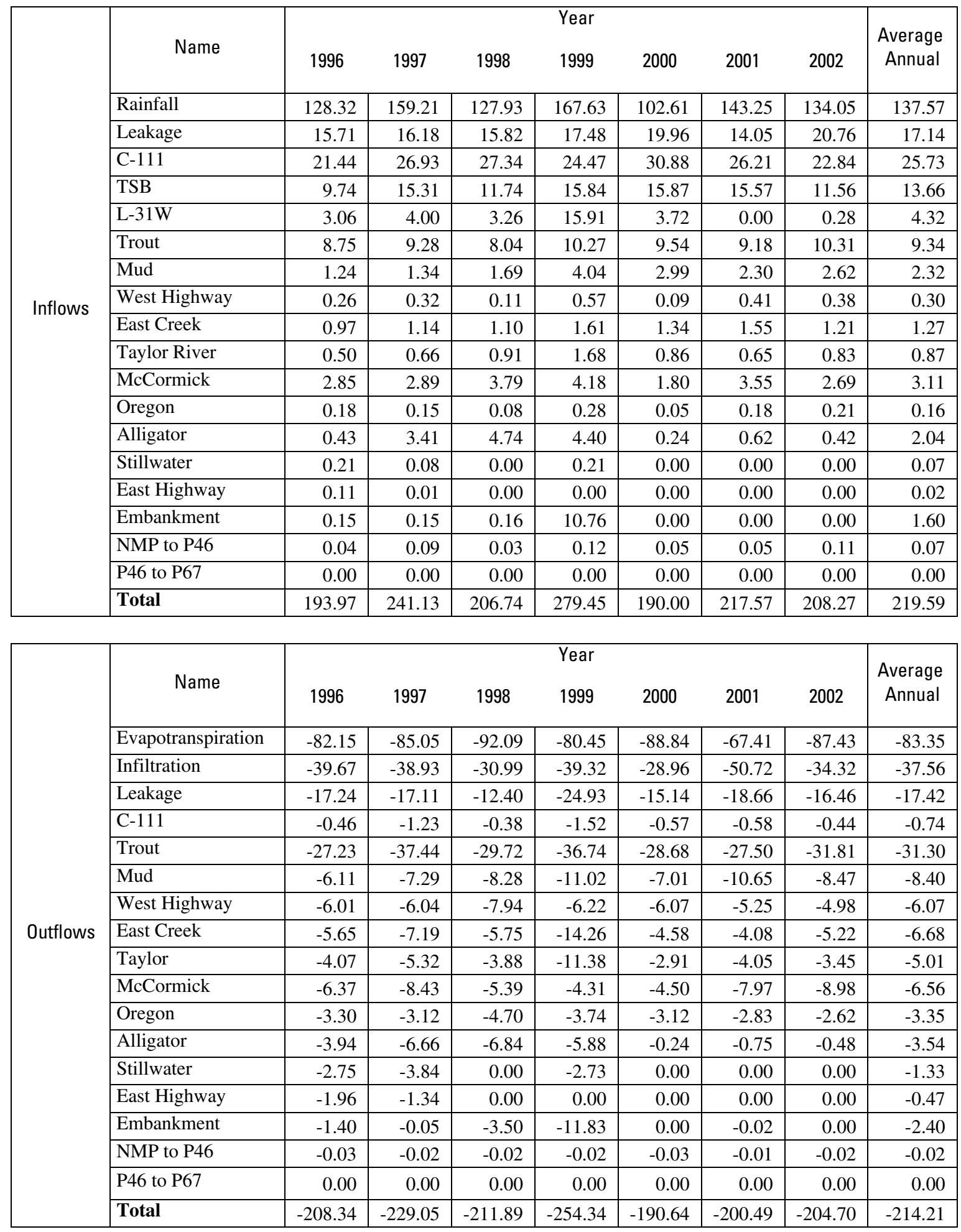




\subsubsection{Surface-Water Flow Patterns}

The average annual water budget for the coastal wetland shows the relative magnitude of the different hydrologic processes and the spatial distribution of surface-water inflows and outflows (fig. 7). Of the average annual rainfall total $(138 \mathrm{~cm}), 83 \mathrm{~cm}$ is lost to surface-water evaporation and $38 \mathrm{~cm}$ is lost to direct infiltration to the water table as a result of dry surface-water cells. The remaining $17 \mathrm{~cm}$ combines with boundary inflows from Taylor Slough Bridge $(13.7 \mathrm{~cm}), \mathrm{L}-31 \mathrm{~W}(4.3 \mathrm{~cm})$, and C-111 $(25.0 \mathrm{~cm})$ and discharges into Florida Bay through the coastal creeks.

Simulation results clearly indicate the presence of spatial and temporal variations in wetland flow velocity. Vector plots of daily average flow velocities were constructed for November 20, 1999, and June 24, 2000, to show wetland flow patterns under wet and dry conditions, respectively (figs. 8 and 9). Vector colors were scaled from 0 to $5 \mathrm{~mm} / \mathrm{s}$ to highlight wetland flow velocity only, rather than wetland and estuary flow velocities, which encompass a much larger range. Arrows are shown for all active surface-water cells with standing water. Figure 8 shows flow velocities for November 20, 1999-a day with relatively high water levels about 33 days after Hurricane Irene, which deposited more than $30 \mathrm{~cm}$ of rain in about 46 hours (Knight and others, 2000). Taylor Slough clearly is a predominant hydrologic feature, with simulated flow velocities that exceed $5 \mathrm{~mm} / \mathrm{s}$. Flow within Taylor Slough does not appear to continue toward the southwest to the Cuthbert and Seven Palms Lake area, but instead appears to be routed toward the southeast into Taylor River, East Creek and Joe Bay (fig. 4). Simulated flow velocities in the eastern part of the wetland model domain also exceed $5 \mathrm{~mm} / \mathrm{s}$. These relatively large velocities are the result of substantial inflows from the watermanagement canals (L-31W and C-111) that were actively draining urban and agricultural areas in the northeast.

For June 24, 2000, a day with relatively dry conditions, standing surface water is absent over much of the area. Over the northern half of the model domain, large areas adjacent to the slough are dry. The topographically high areas surrounding the southwestern lakes are also dry (fig. 9). Although Taylor Slough has standing water, flow velocities are less than $1 \mathrm{~mm} / \mathrm{s}$. On the eastern side of the model, there is inflow from the C-111 canal, but in general, wetland flow velocities for June 24, 2000, are 5 to 10 times less than for November 20,1999. Model results also show that simulated flow velocities within Florida Bay generally are about 1 to 3 orders of magnitude greater than wetland flow velocities because of the lower frictional resistance values (Manning's $n$ ) and larger depths assigned to Florida Bay.

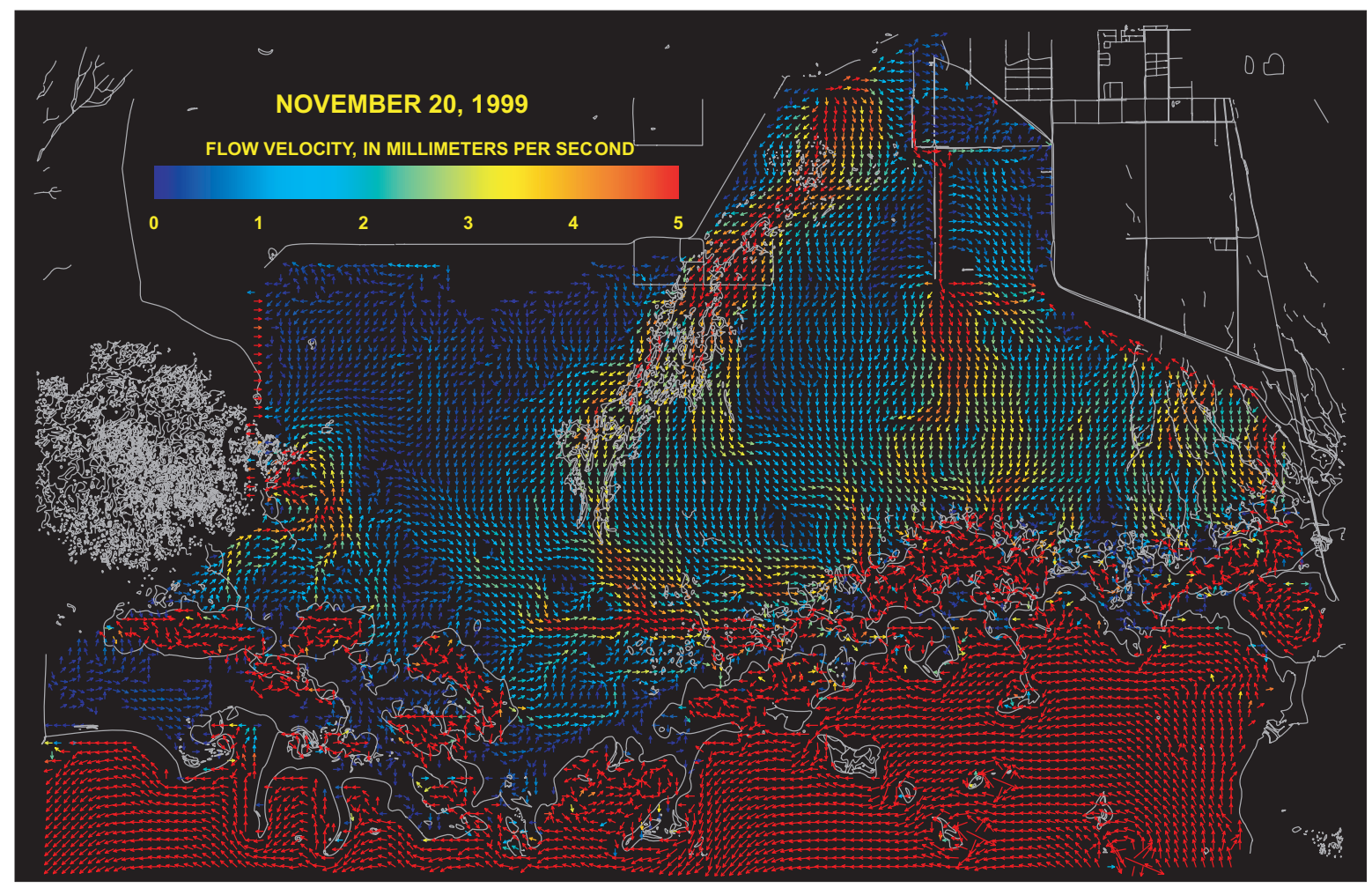

Figure 8. Daily average surface-water flow velocities for November 20, 1999, during a relatively wet period. 


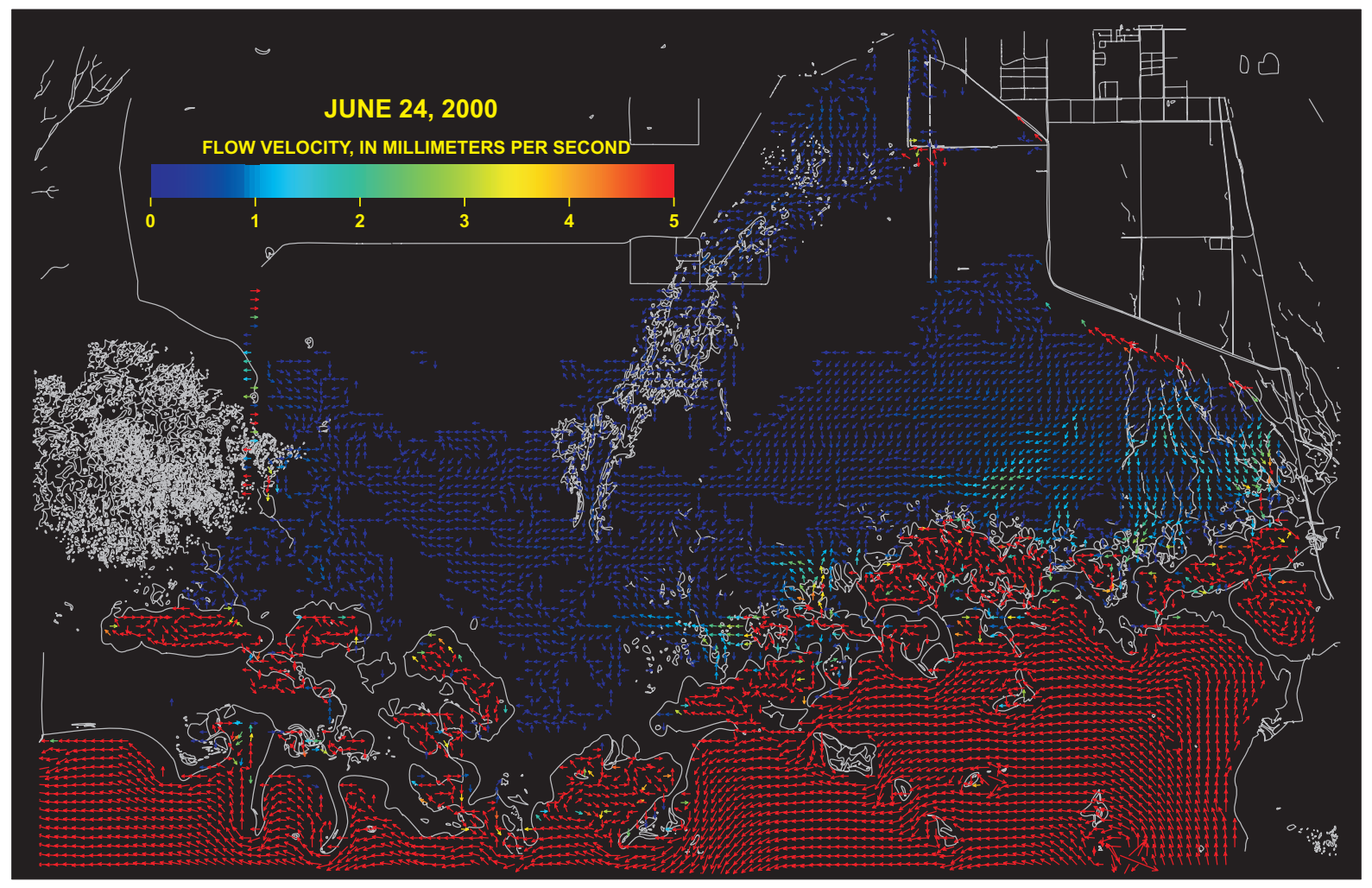

Figure 9. Daily average surface-water flow velocities for June 24,2000 , during a relatively dry period.

\subsubsection{Discharge to Florida Bay and Surface-Water/Ground-Water Interactions}

Discharge of fresh or brackish water from the Florida mainland into northeastern Florida Bay can occur in three ways: (1) discharge from coastal creeks, (2) overtopping of the Buttonwood Embankment, and (3) submarine groundwater discharge. Of these three discharge mechanisms, coastal creek discharge is the only one that has been directly measured in the field, and continuous measurements for 1996 to 2002 are available at 5 of the 10 coastal creeks in the area. For the five creeks with continuous discharge measurements for the 7-year simulation period (McCormick, Mud, Trout, Taylor River, and West Highway), the simulated cumulative discharge is only about 15 percent less than the measured cumulative discharge (fig. 10). Based on model results, cumulative discharge estimates for the five coastal creeks without continuous record for the simulation period (Alligator, East, Stillwater, Oregon, and East Highway) comprise about 24 percent of the measured cumulative discharge at the five monitored creeks. The frictional resistance parameters of the creeks without continuous data were not altered from their original values, which were assigned based on field observations of creek widths and literature values for roughness coefficients.

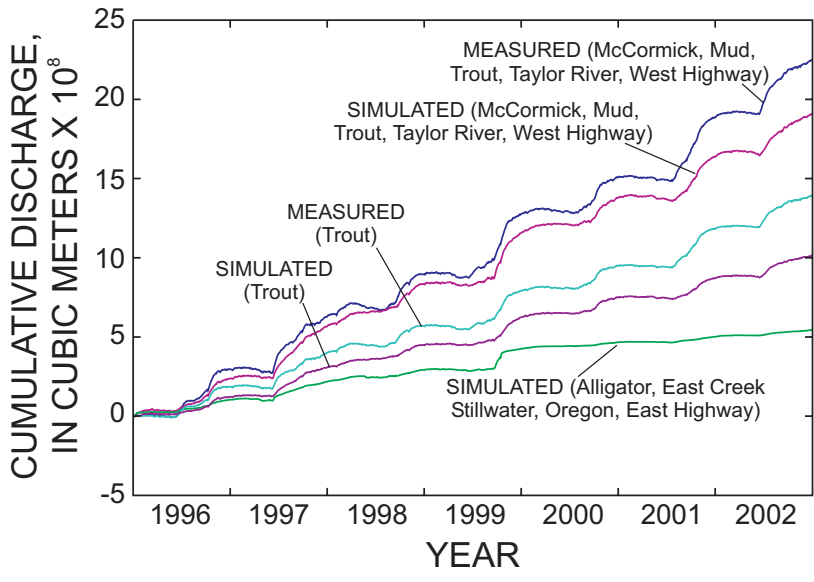

Figure 10. Measured and simulated cumulative discharge for the five measured creeks, Trout Creek, and the five creeks without continuous measurements for the 7-year simulation period (1996-2002). 


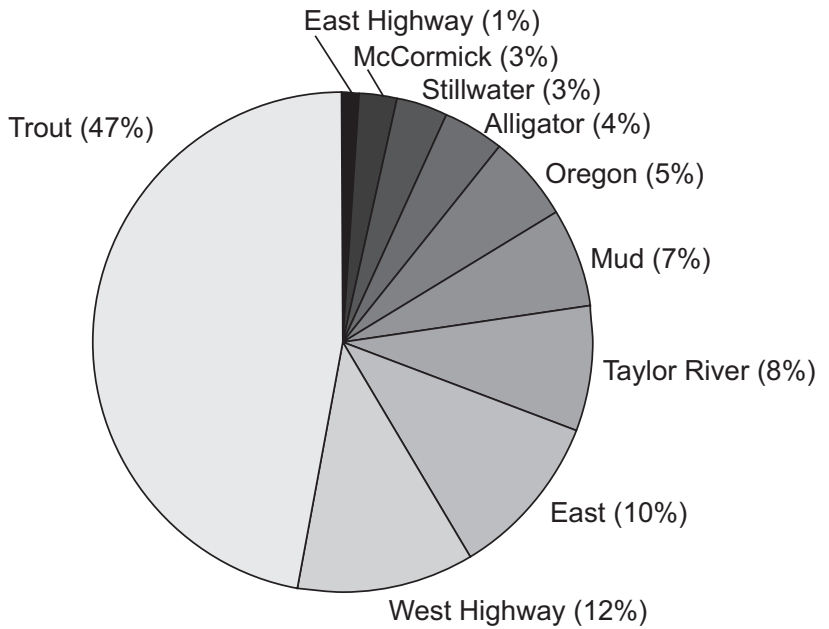

Figure 11. Ranking of the coastal creeks by cumulative discharge volume to Florida Bay for the period from 1996 to 2002.

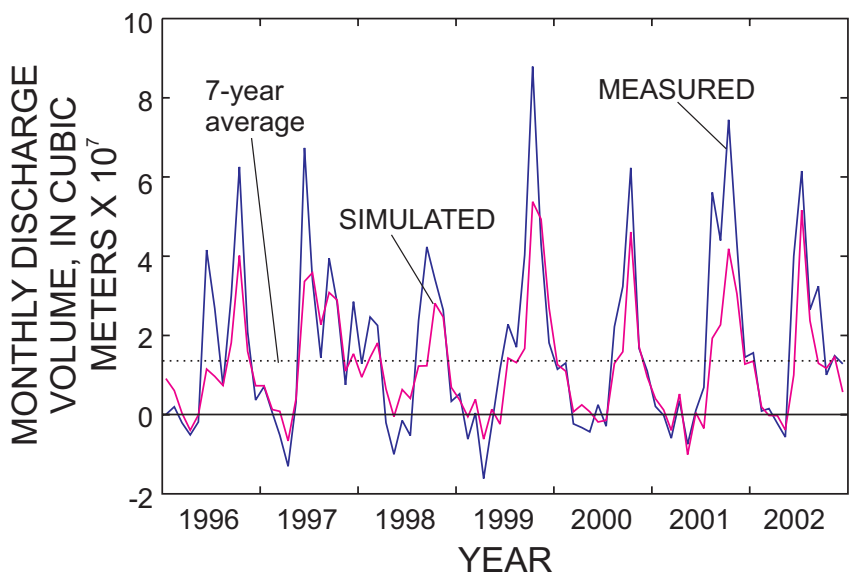

Figure 12. Measured and simulated monthly discharge at Trout Creek from 1996 to 2002.

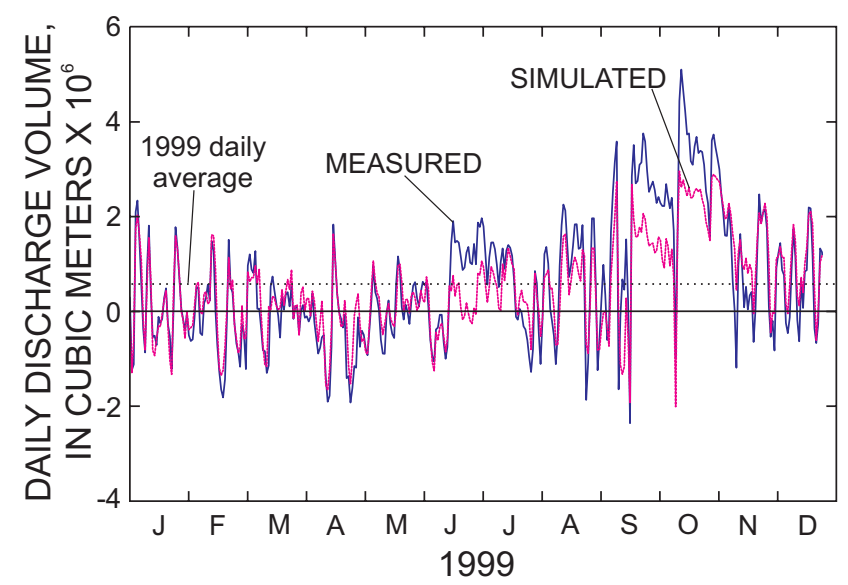

Figure 13. Measured and simulated average daily discharge at Trout Creek for 1999.
The distribution of coastal creek discharge to Florida Bay was evaluated by using measured discharge volumes for the five creeks with continuous data for the 7-year simulation period and simulated discharge volumes for the remaining five creeks. For the 7-year simulation period, Trout Creek contributed nearly half (47 percent) of the discharge to Florida Bay (fig. 11). West Highway, East, Taylor River, and Mud Creeks were the next largest contributors with $12,10,8$ and 7 percent of the total discharge, respectively. The five remaining creeks (Oregon, Alligator, Stillwater, McCormick, and East Highway) each contributed 5 percent or less of the total discharge.

The coastal creeks show distinct seasonal patterns in discharge to Florida Bay. For example, at the monthly timescale, simulated and measured discharges at Trout Creek peak during the wet season and reverse directions during most dry seasons (fig. 12). Discharge volumes begin to increase with the onset of the wet season, which typically occurs between May and June. By September or October of each year, discharge volumes reach their annual peaks and then begin to decline as the dry season approaches in November. During some dry season months, discharge rates are negative, which indicate northward flow from Florida Bay into the coastal wetlands. These negative discharge rates, which are reproduced by the model, are primarily caused by sustained periods of southerly winds that push brackish Florida Bay water inland. The ability of the model to match these negative discharge values proved to be critical in accurately representing salinity values in the coastal wetlands. For the entire 7-year period, the average monthly discharge volume calculated with measured data is $1.7 \times 10^{7} \mathrm{~m}^{3}$ (fig. 12). The average monthly discharge volume calculated using simulated data is $1.2 \mathrm{x}$ $10^{7} \mathrm{~m}^{3}$, about 27 percent too low. Using the measured and simulated records in fig. 12 , the $\mathrm{R}^{2}$ value is 0.77 . This discrepancy appears to be caused by failure of the model to capture peak flows during the wet season. A possible explanation is that one or more of the inflows represented by the model is based on inaccurate field data. The model is highly sensitive to rainfall, and small errors in rainfall values, when applied to a large area, can lead to substantial errors in creek discharge. At shorter timescales, negative discharge values occur frequently throughout the year. Figure 13 shows daily discharge volumes at Trout Creek for 1999. Again, the model seems to represent the range in discharge volumes, capturing both the high and low values. The model does, however, fail to represent some of the higher peaks, which results in a 20-percent underestimation of average annual discharge volume at Trout Creek for 1999. Using daily average flows, the $R^{2}$ value for measured and simulated discharges at Trout Creek is 0.78 .

Spectral analysis was performed on discharge data at Trout Creek to determine if the dominant frequencies observed in the field measurements are represented by the model. Figure 14 shows an amplitude spectrum of measured and simulated discharge for the 7-year dataset at Trout Creek. Four distinct spikes in the spectrum are shown at frequencies of $0.93,1.00,1.93$, and 2.00 cycles per day in both the measured and simulated discharges. The spike at 0.93 corresponds to the $\mathrm{O} 1$ tidal component, which has a period of 25.8 hours. At this frequency, the amplitude spectrum values for the measured and simulated discharges are 0.209 and $0.208 \mathrm{~m}^{3} / \mathrm{d}$, respectively. The 1.00 and 2.00 cycles per day frequencies 
correspond to periods of 24 and 12 hours, respectively, and are caused by temporal variations in wind, and possibly the S1 and $\mathrm{S} 2$ solar tides. Dominant spikes at the 1.00 and 2.00 frequencies are also seen in the spectrum of wind velocity (not shown) collected at the Joe Bay weather station. At the 1.00 cycle per day frequency, the amplitude spectrum values for the measured and simulated discharge are 0.529 and $0.763 \mathrm{~m}^{3} / \mathrm{d}$, respectively. At the 2.00 cycle per day frequency, the amplitude spectrum values for the measured and simulated discharge are 0.394 and $0.428 \mathrm{~m}^{3} / \mathrm{d}$, respectively. The spike at the 1.93 frequency corresponds to the M2 lunar tide. At this frequency, the simulated amplitude spectrum $\left(0.199 \mathrm{~m}^{3} / \mathrm{d}\right)$ is less than half of the measured amplitude spectrum $\left(0.512 \mathrm{~m}^{3} / \mathrm{d}\right)$. A harmonic analysis of Trout Creek stage indicates that the M2 amplitude is $0.38 \mathrm{~cm}$, which is only slightly larger than the precision of the stage recorder $(0.30 \mathrm{~cm})$. Thus, a possible explanation for the discrepancy between the simulated and measured amplitude spectrum at the M2 frequency is that the boundary stages in the model are not recorded with enough precision to reproduce the complete M2 signal.

Buttonwood Embankment overtopping is another mechanism that discharges freshwater from the coastal wetlands into Florida Bay. Due to the remote location and expansive length of the embankment, however, overtopping discharge volumes have never been measured. Elevations of the embankment crest are not available, except at the coastal creeks where estimates can be made based on the height of the embankment above the water surface. In the model grid, the embankment height is set at $0.3 \mathrm{~m}$ above land surface. Simulation results indicate that embankment overtopping is infrequent, but can occur in both directions in response to tropical storms. For example, as Hurricane Irene approached the Florida mainland in October 1999, a storm surge was recorded at the Taylor River monitoring station (fig. 15). This storm surge pushed a large volume of brackish water from Florida Bay over the embankment and into the coastal wetlands. After Hurricane Irene made landfall, the associated heavy rainfall reversed flow over the embankment and into Florida Bay, as indicated by the positive discharge values (fig. 15). This was the largest overtopping event simulated by the model. For the entire 7-year simulation period, the net overtopping discharge volume was $-3.7 \times 10^{7} \mathrm{~m}^{3}$. This suggests that although overtopping may allow for flow into the coastal wetlands, the mechanism is not a substantial source of freshwater for Florida Bay. The cumulative positive and negative overtopping discharge volumes are $7.3 \times 10^{7} \mathrm{~m}^{3}$ and $-1.1 \times 10^{8}$ $\mathrm{m}^{3}$, respectively, which are relatively small compared to the cumulative creek volumes for the 7year simulation period (about $28 \times 10^{8} \mathrm{~m}^{3}$ for the 10 coastal creeks). At daily, weekly, or monthly timescales, however, the overtopping volumes may be significant in terms of freshwater flows into Florida Bay, or brackish water flow into the

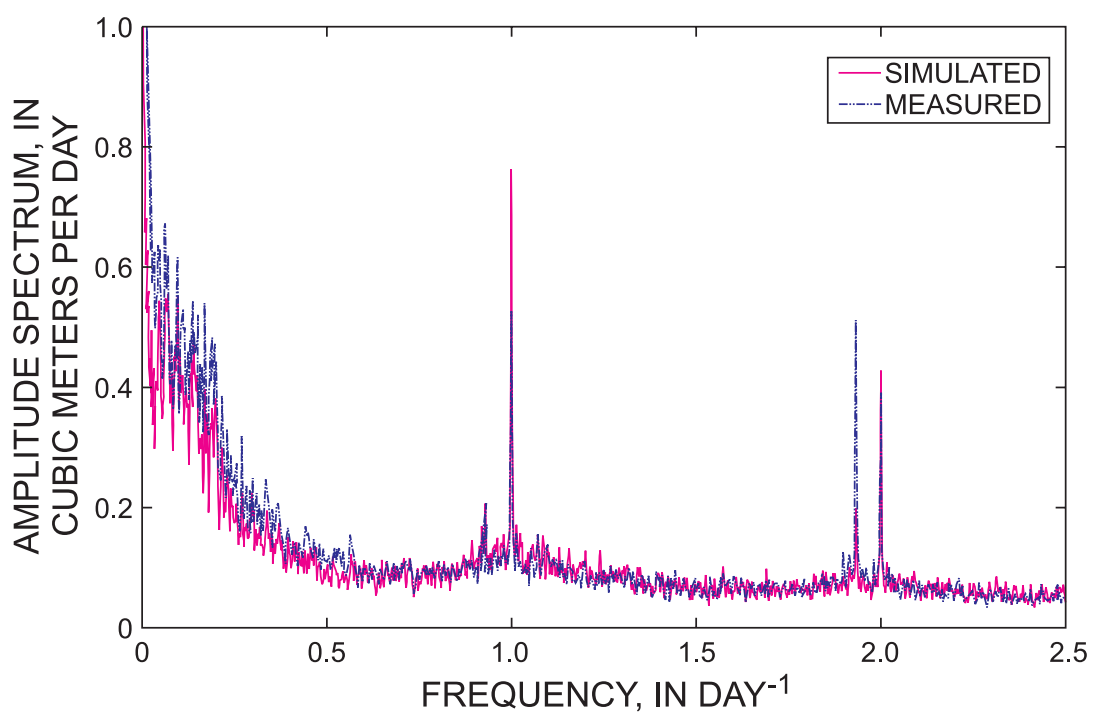

Figure 14. Amplitude spectrum as a function of frequency calculated using 2-hour measured and simulated discharges at Trout Creek for the 7-year simulation period.

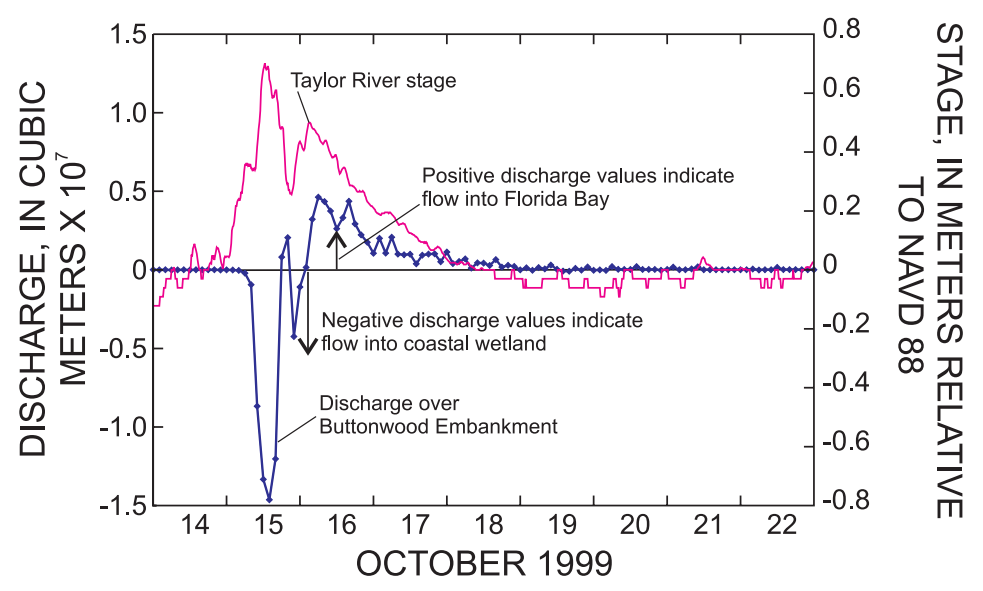

Figure 15. Discharge over Buttonwood Embankment and stage at Taylor River during Hurricane Irene, October 1999. coastal wetland.

Daily leakage rates between surface water and ground water are produced as part of the model output for each cell. These daily leakage rates were averaged over the 7-year simulation period to illustrate the spatial variability of surface-water/groundwater interaction and to determine whether ground water is discharging into Florida Bay. These leakage rates do not include recharge or evapotranspiration directly to or from the water table. The model suggests an alternating pattern of downward and upward leakage from north to south (fig. 16). Within the wetland portion of the model domain, downward leakage rates (shown as 


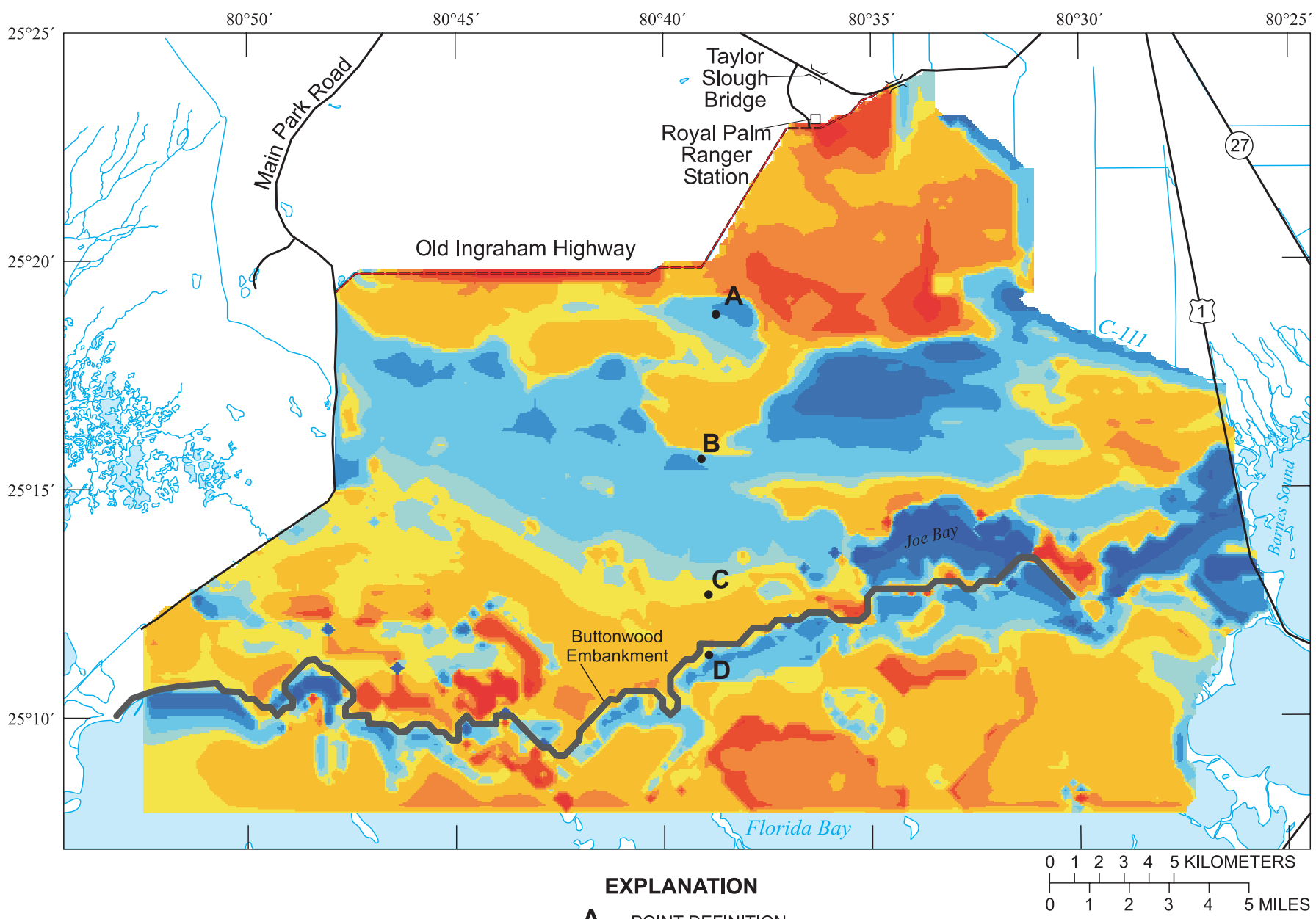

- A POINT DEFINITION

AVERAGE SIMULATED LEAKAGE RATE, IN CENTIMETERS PER DAY

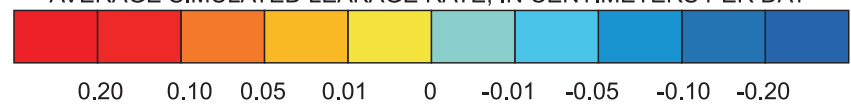

Figure 16. Average annual leakage rates for the 7-year simulation period.

positive values) correlate with topographically high areas. For example, in the northern part of the model, average leakage rates exceed $0.2 \mathrm{~cm} / \mathrm{d}$. A band of upward leakage with rates in some areas exceeding $0.2 \mathrm{~cm} / \mathrm{d}$ appears across the central part of the model. This upward leakage band correlates with the topographically low area within the central part of the model (fig. 5) and with the freshwater/saltwater interface in the aquifer (fig. 4). Downward leakage rates also occur just north of the Buttonwood Embankment where surface-water levels tend to be higher than those in Florida Bay. These model results suggest that there may be shallow ground-water flow beneath the embankment, which then discharges into Florida Bay. The source for this shallow ground-water flow system is surface water impounded by the Buttonwood Embankment. South of the Buttonwood Embankment, ground water discharges upward into the coastal embayments of Florida Bay. Average leakage rates within this zone can exceed $0.2 \mathrm{~cm} / \mathrm{d}$, but most are between 0.01 and $0.1 \mathrm{~cm} / \mathrm{d}$. Model results also indicate that Joe Bay (figs. 4 and 16) may be a ground-water discharge area. Joe Bay has an exposed limestone bottom, and thus, the absence of a thin layer of low-permeability sediments results in a relatively strong hydraulic connection between surface water and the underlying aquifer. Average leakage rates appear to be downward over most of Florida Bay (figs. 4 and 16), with values ranging between about 0.0 and $0.2 \mathrm{~cm} / \mathrm{d}$. Downward leakage in this zone is probably the result of cyclic flow that often occurs in freshwater/saltwater interfaces within a coastal aquifer (Kohout, 1964; Langevin, 2001). Fresh ground water flowing toward an interface mixes with saline ground water. This brackish mixture then discharges into the ocean, coastal estuary, or in this case, into the brackish water wetlands.

Average leakage rates for the entire simulation period are shown in (fig. 16); however, daily leakage rates are highly variable and can change direction in response to rainfall events or prolonged dry periods. Mapped leakage patterns for specific days and averaged periods are similar, except after large rainfall events. Graphs of simulated daily leakage and water levels were prepared for selected model cells (labeled A-D in fig. 16). The average leakage rate is about $-0.05 \mathrm{~cm} / \mathrm{d}$ at point A (fig. 17), which is in a 

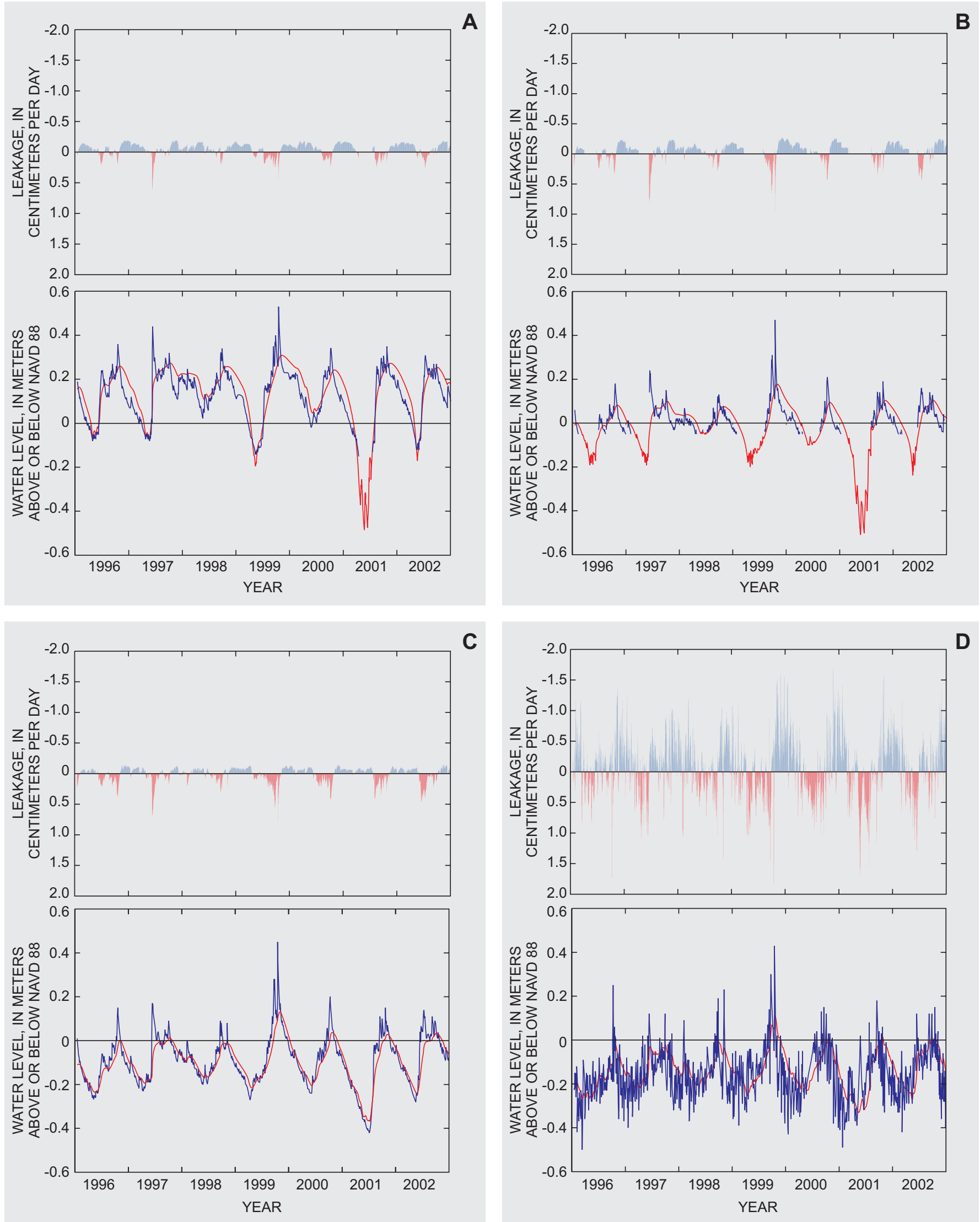

Figure 17. Simulated leakage rates, surface-water stage, and ground-water head at four locations. 
zone of upward leakage just south of Old Ingraham Highway (fig. 16). During most of the simulation period, leakage at point A is upward. Large rainfall events, such as in June 1997, however, seem to greatly affect the vertical movement of water. Vertical leakage in the area during these events appears to change direction, with surface-water flowing downward into the aquifer. Temporally variable leakage patterns similar to location A also are shown for points B and C (fig. 17); downward leakage rates into the aquifer are relatively high after large rainfall events. During periods when surface-water levels decline between rainfall events, ground water appears to leak gradually upward and mix with the surface water. Point D in Florida Bay (fig. 16) appears to respond differently than the other locations, possibly because it is highly affected by the stage and salinity of Florida Bay (fig. 17). Simulated ground-water leakage rates at location $D$ range from -1.7 to $1.7 \mathrm{~cm} / \mathrm{d}$, with an average rate of $-0.09 \mathrm{~cm} / \mathrm{d}$. The water budget for the coastal wetland part of the model domain indicates that average volumes of ground-water recharge and discharge are nearly identical for the simulation period (fig. 7 and table 3). For any particular year, however, the wetland may experience a net loss or gain as a result of leakage (table 3 ).

Simulated exchange rates between surface water and ground water contain some degree of uncertainty, with perhaps the exception of northern Taylor Slough, because the model was not calibrated to direct leakage measurements. Harvey and others (2000a) suggest that leakage rates into the northern part of Taylor Slough (south of Old Ingraham Highway) may be as much as $3 \mathrm{~cm} / \mathrm{d}$. The simulated leakage rate (about $0.25 \mathrm{~cm} / \mathrm{d}$ for the same area and month), however, is an order of magnitude lower than the maximum measured rate, but is in the correction direction (upward) and probably within the error range of the chloride dilution method used for the calculation. Harvey and others (2000b) also measured head differences across the peat layer at 11 locations during six different field visits. To compare these field measurements with the model, simulated ground-water heads from layer 1 were converted from equivalent freshwater heads to aquifer heads and then subtracted from overlying surface-water stages to calculate simulated head differences across the peat. Numerous simulations were performed with varying hydraulic properties for the peat and uppermost aquifer layer in an effort to calibrate the model. For the 36 head-difference measurements, the mean and mean absolute errors between the simulated and measured values are -0.9 and $5.2 \mathrm{~cm}$, respectively. Comparisons of simulated head differences with the observed head differences indicate that many of the simulated directions of vertical leakage are correct. Discrepancies between simulated and measured values are likely caused by variations in field head differences that occur over distances shorter than the 305-m cell size used in the model, or by the presence of a complex and heterogeneous peat layer with spatially variable hydraulic properties.

\subsubsection{Coastal Salinities}

Field data and model results indicate a strong seasonal pattern in coastal wetland salinities. Figures 18 and 19 are maps of daily average surface-water salinities for November 20, 1999, and for June 24, 2000, respectively. These dates are the same as used in figures 8 and 9 to show daily average surface-water flow velocities. During the wet season, salinities for most of the coastal wetlands are nearly zero, except for several isolated areas north of the Buttonwood Embankment where salinities are less than about 10 psu (figs. 4 and 18). In Florida Bay, salinities on November 20, 1999, are much less than the salinity of seawater. For example, in Little Madeira Bay, salinities near the mouths of East Creek and Taylor River are about 5 to 10 psu. Salinities farther offshore range between about 15 and 25 psu. The salinity pattern is quite different for June 24, 2000 (fig. 19). Salinities from 5 to 10 psu have extended into the coastal wetlands west of Joe Bay. The simulated salinity in Joe Bay ranges between about 15 and 23 psu (figs. 4 and 19). Most of the Florida Bay area, except for Little Madeira Bay, Long Sound, and Little Blackwater Sound (shown on fig. 4), has seawater salinities of about 35 psu. A comparison between measured and simulated values of average monthly salinity at Trout Creek is shown in figure 20. The field measurements and simulation clearly indicate season fluctuations in salinity at Trout Creek. Salinities reach 35 psu in May, June, or July of each year, which corresponds with the end of the dry season. The lowest salinities were recorded in August, September, or October of each year. Using the average monthly data in figure 20 , the measured and simulated salinities have an $\mathrm{R}^{2}$ value of 0.76 . A comparison of

daily salinities gives an $\mathrm{R}^{2}$ value of 0.67 , suggesting that the model is better at representing the longer seasonal fluctuations than the shorter timescale daily or weekly salinity fluctuations. 


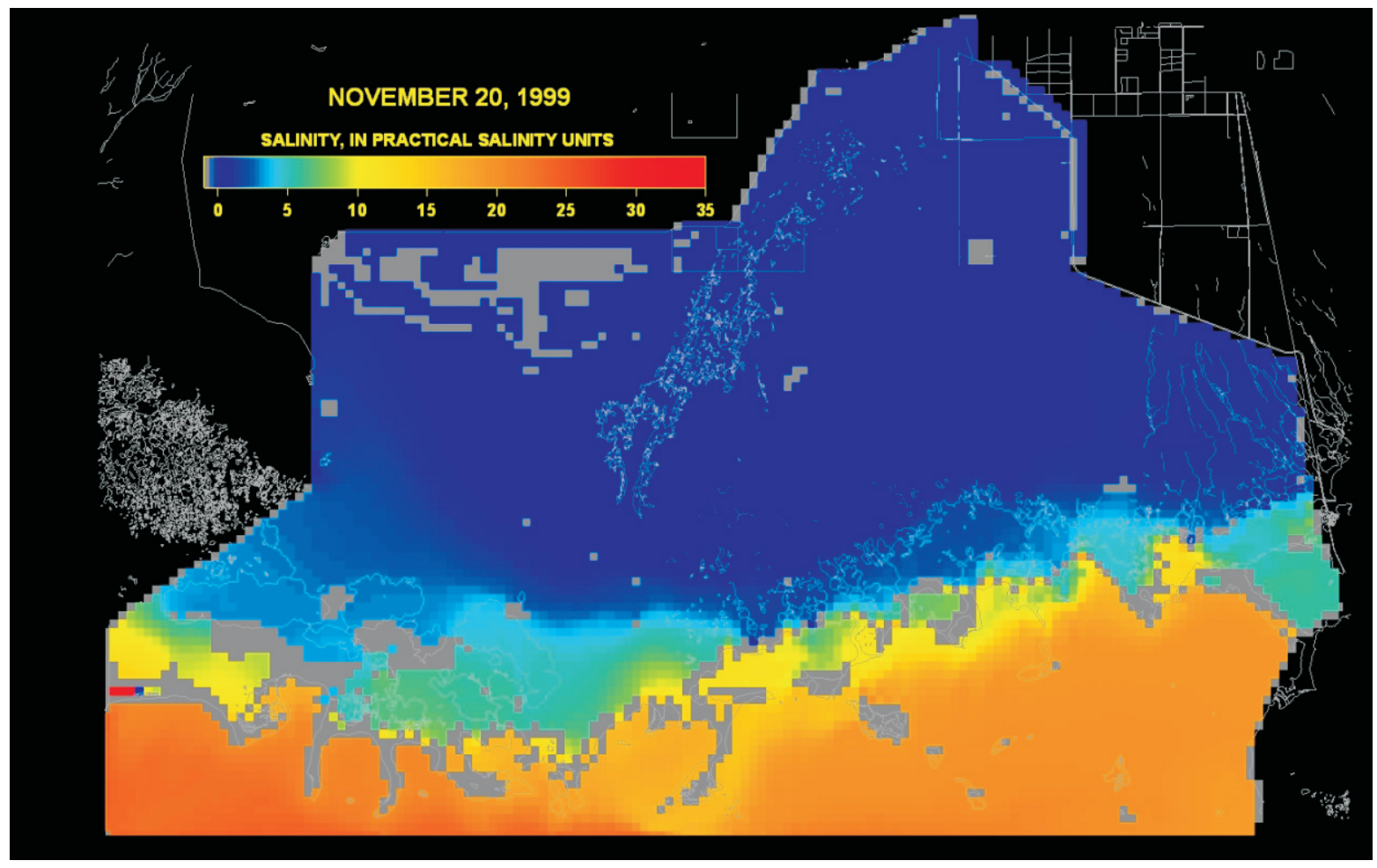

Figure 18. Daily average surface-water salinities for November 20, 1999, during a relatively wet period.

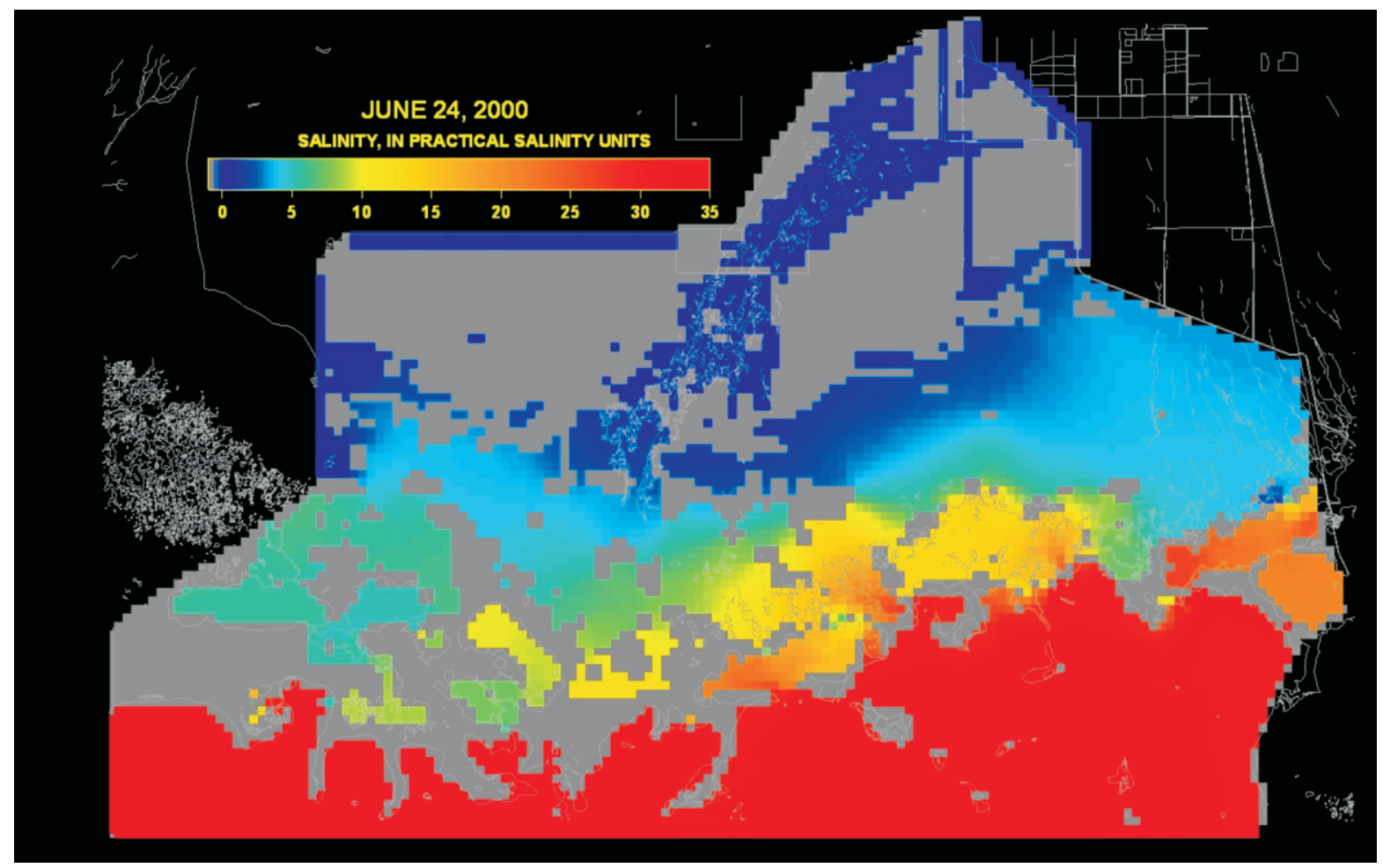

Figure 19. Daily average surface-water salinities for Junen 24,2000 , during a relatively dry period. 


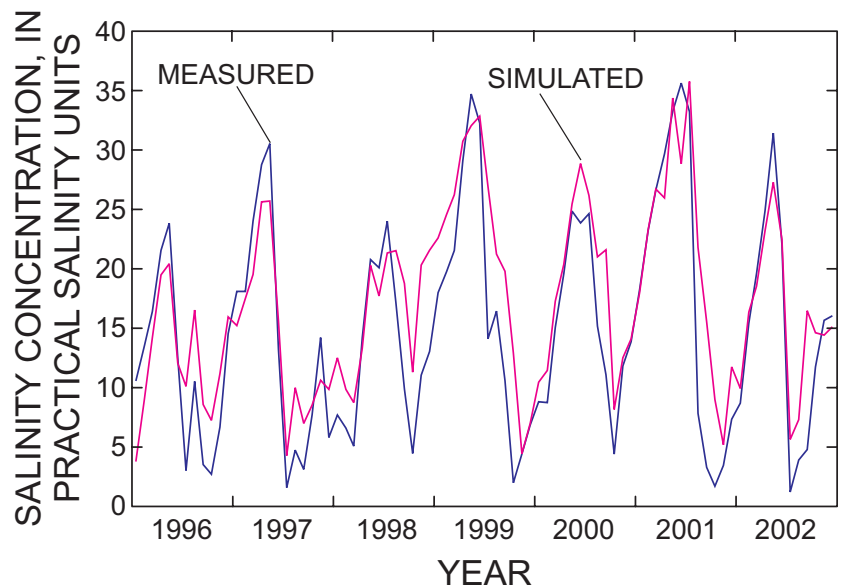

Figure 20. Measured and simulated values of monthly average salinity at Trout Creek for the 7-year simulation period (1996-2002)

\subsection{Effects of Selected Hydrologic Processes}

Several simulations were performed to evaluate the effects of hydrologic processes unique to this particular model application, namely (1) surface-water and ground-water interactions, (2) density-dependent flow, and (3) local wind stress. These three processes are all known to be active within the study area, and thus, their effects can be evaluated by comparing simulations without these processes to the previously described integrated simulation, referred to here as the base case. A possible limitation with this approach is that the consequences for neglecting a process may be overstated if calibration of the integrated model tended to overemphasize that process.

The ground-water part of the integrated model was calibrated to heads at three monitoring wells (G-3619, G-3353, G-1251), 36 head-difference measurements, the position of the freshwater/saltwater interface, and to estimates of leakage. Further adjustments to the ground-water model did not improve simulation results, and thus the integrated model was considered calibrated within the limitations of the trial and error method. The effect of leakage on the surfacewater system was evaluated by removing the ground-water model. Neglecting surface-water and ground-water interactions tends to worsen simulated discharges and salinities in most cases. Mean absolute errors (MAE) and root mean square errors (RMSE) for the simulation without leakage (table 4) are larger (with the exception of salinity errors at McCormick Creek and Taylor River) than errors for the base case (table 2). The average increases in MAE and RMSE for coastal creek discharge as a result of neglecting leakage are 0.54 and $0.94 \mathrm{~m}^{3} / \mathrm{d}$, respectively. The average increases in MAE and RMSE for coastal creek salinity are 0.14 and 0.19 psu, respectively.

In the second simulation, fluid density was held constant in space and time by adjusting the equation of state (eq. 5) such that concentration did not affect fluid density. The resulting cumulative flow through the five measured creeks $\left(1.73 \times 10^{9} \mathrm{~m}^{3}\right)$ is about 9 percent less than for the base case simulation $\left(1.91 \times 10^{9} \mathrm{~m}^{3}\right)$ and about 24 percent less than the measured cumulative discharge $\left(2.25 \times 10^{9} \mathrm{~m}^{3}\right)$. There is little difference in cumulative discharge for the five creeks without continuous data $\left(4.60 \times 10^{8} \mathrm{~m}^{3} \mathrm{com}-\right.$ pared with $5.43 \times 10^{8} \mathrm{~m}^{3}$ for the base case). Some minor differences between this simulation and the base case were noted for leakage rates, but in general the leakage pattern is similar to that for the base case (fig. 16). These results, therefore, indicate that the upward leakage zone located between $\mathrm{A}$ and $\mathrm{C}$ in figure 16 is caused by topographic variations rather than by variable-density effects near the relatively dense saltwater wedge observed in the Biscayne aquifer.
Table 4. Calibration statistics for the surfacewater simulation without leakage. Errors are calculated relative to field data for daily average coastal creek discharges and coastal creek salinities. Mean errors were calculated by subtracting measured values from simulated values. Station locations are shown in figure 4.

[ME, mean error; MAE, mean absolute error; RMSE, root mean square error; $\mathrm{m}^{3} / \mathrm{s}$, cubic meters per second; $\mathrm{m}$, meter; psu, practical salinity units].

\begin{tabular}{|c|c|c|c|}
\hline Station & ME & MAE & RMSE \\
\hline \multicolumn{4}{|c|}{ Discharge $\left(\mathrm{m}^{3} / \mathrm{s}\right)$} \\
\hline McCormick & 0.78 & 2.62 & 4.98 \\
\hline Mud & 0.25 & 2.40 & 4.32 \\
\hline Trout & -2.13 & 5.74 & 7.86 \\
\hline Taylor River & -0.06 & 1.50 & 3.40 \\
\hline West Highway & -0.29 & 1.18 & 1.65 \\
\hline \multicolumn{4}{|c|}{ Salinity (psu) } \\
\hline McCormick & 2.19 & 6.18 & 7.53 \\
\hline Mud & -2.05 & 5.04 & 6.48 \\
\hline Trout & 2.36 & 5.45 & 7.00 \\
\hline Taylor River & 1.78 & 4.84 & 5.74 \\
\hline West Highway & 4.97 & 6.10 & 8.45 \\
\hline
\end{tabular}


The local wind stress was removed for the third simulation. A distinction is made here between local and regional wind effects. In SWIFT2D, the local wind stresses are included in the conservation of momentum equations (eqs. 2 and 3 ). The model allows input of temporally and/or spatially varying wind speed and direction for calculation of stress. On the other hand, regional wind effects are included in the limited domain model through specified water-level boundaries. For example, a strong southerly wind over Florida Bay will push water against the Buttonwood Embankment and raise water levels in northeastern Florida Bay. Thus, the water levels measured in northeastern Florida Bay, which are used to assign the southernmost stage boundary for the model, contain the effect of the regional wind field. Removing the local wind stress does not have a substantial effect on coastal creek flows, but does affect coastal salinities. As an example, daily average salinities at Trout Creek from November 2001 to July 2002 are shown in figure 21. Clearly, the simulation is improved when the local wind stress is included in the model, both in terms of the short-term fluctuations observed at the end of the 2001 wet season and in terms of the longer time increase in salinity as a result of the dry season.

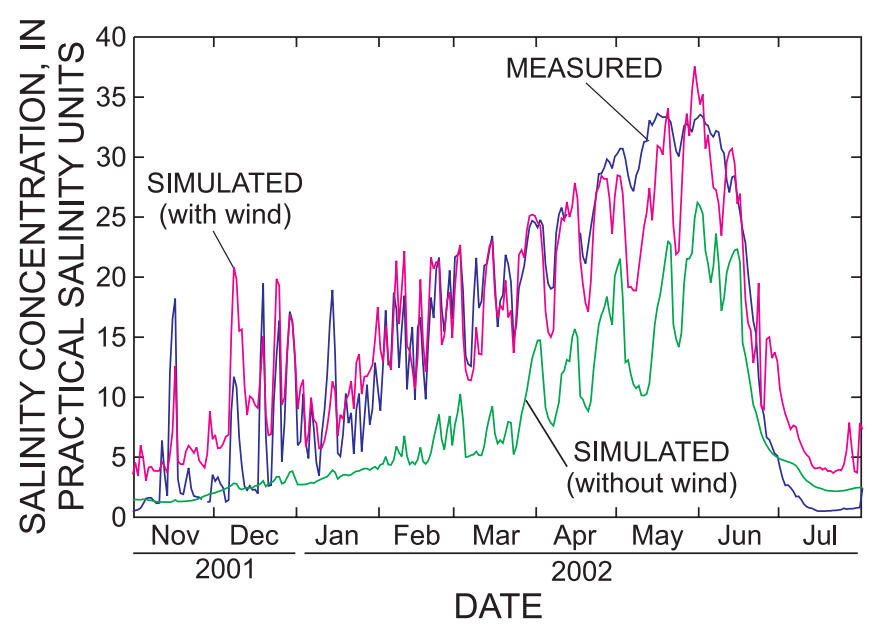

Figure 21. Average daily salinity at Trout Creek from simulation without local wind stress, the base case simulation, and from measured data.

\section{Discussion}

Prior to performing simulations with the integrated model, the surface-water and ground-water models were independently developed and calibrated to the extent possible. For the initial surface-water model, exchange with ground water was considered negligible (Swain and others, 2004). Ground-water model development was performed after the surface-water model was developed, and thus simulated surface-water stages and salinities were applied as boundary conditions over the aquifer surface. This stepwise approach had two advantages. First, it was relatively easy to identify and correct input and runtime errors for the individual models before they were integrated. Second, computer runtimes for the ground-water model were only a couple of hours, whereas the integrated model required over 30 hours to run. The shorter computer runtimes were particularly useful during calibration of the ground-water model to aquifer salinity. Because of the highly transmissive nature of the Biscayne aquifer and a relatively stable freshwater/saltwater interface in southern Florida (Sonenshein, 1997), aquifer salinities were assumed to be in equilibrium with current water levels and hydrologic stresses. Thus, an additional level of confidence in the ground-water model was established when it could be shown that after the model reached dynamic equilibrium (through repeated simulations), the simulated freshwater/saltwater interface was in the observed location. Only minor salinity adjustments at the ground-water boundaries were required as part of this calibration process as hydrodynamic dispersion was not active for the simulations.

Limitations were periodically encountered using the explicit, time-lagged approach to couple the surface-water and groundwater models. For some sensitivity simulations with very large leakage rates, convergence could not be achieved during solution of the ground-water flow equation. Evaluation of the convergence problems indicated that very large leakage rates caused numerical oscillations in the implicit solution. Ground-water heads measured in the field can respond quickly to hydrologic stresses. For the Everglades application of the integrated model, however, large leakage rates may persist throughout the day in the model, because of the 1-day length of the stress period in SEAWAT, whereas actual leakage rates would decrease as ground-water heads respond more quickly. These convergence problems could probably have been avoided by decreasing the length of the groundwater stress period. These convergence problems were encountered only in a few instances, and thus the day lag, which is computationally many times faster than using an hourly lag or fully implicit solution, was a necessity for this particular application. Future efforts using the integrated model should follow the example of Fairbanks and others (2001) and focus on determining the relation between accuracy and efficiency for different coupling approaches and timestep lengths.

The Buttonwood Embankment clearly is an important physiographic feature in the Taylor Slough area. Model results and field observations suggest that freshwater flow into Florida Bay occurs primarily through the coastal creeks, rather than as overtopping of the embankment. This flow pattern has allowed field investigations to quantify with a high level of certainty the flow exchanges between the coastal wetlands and Florida Bay (Hittle, 2000; Hittle and others, 2001). Confidence in the predictive capability of the integrated model is due largely to the accuracy and long-term record length of creek discharge data. Many coastal wetlands in other 
locations, however, are not separated from the adjacent marine water body by an embankment or barrier to overland flow, and thus measurement of freshwater outflows is not as straightforward.

The integrated model described here represents numerous hydrologic processes and requires extensive data input to simulate the flow and salinity patterns for the 7-year period. Consequently, the model is subject to numerous limitations, and model results should be used with caution, particularly results for which there are no measured values. For example, estimates of Buttonwood Embankment overtopping discharge volumes contain a high level of uncertainty, because the crest elevation of the embankment is more variable than specified in the model. Simulated leakage rates also contain a high level of uncertainty, particularly those in the southern part of the coastal wetland and northeastern Florida Bay where field estimates of surface-water and ground-water interactions are lacking. Future applications that use forcing conditions outside the range of values used for calibration would also be subject to limitations. Although these limitations are present, comparisons between simulated and observed flow and salinity patterns in both the wetland and aquifer indicate that important system processes and behavior are represented by the model. The model clearly reproduces the gradual salinity increase during the dry season and subsequent freshwater flush during the wet season. For the 7-year simulation period, simulated rates of freshwater discharge to Florida Bay are only 15 percent less than measured discharges. For these reasons, the model seems well suited to serve its intended purpose of predicting the effects of Everglades restoration on flows, stages, and salinities in the coastal wetlands, provided the model's limitations are carefully considered in the evaluation of predictions.

\section{Summary and Conclusions}

This paper describes a numerical approach for simulating integrated surface-water/ground-water flow and solute transport in coastal wetlands and adjacent estuaries. The approach combines the SWIFT2D two-dimensional hydrodynamic flow and solutetransport code with the SEAWAT three-dimensional, saturated ground-water flow and solute-transport code. The surface-water and ground-water models, which both simulate density-dependent flow, are coupled using an explicit time-lagged approach based on a variable-density form of Darcy's law to calculate the leakage flux at the ground surface; solute mass transfer between surface water and ground water is assumed to occur only by leakage advection.

The integrated code was applied to the southern Everglades of Florida and northeastern Florida Bay to quantify flow and salinity patterns for the period 1996-2002 and to evaluate the effects of selected hydrologic processes. The model was calibrated to a wide range of field data, including coastal creek flows through the Buttonwood Embankment, a narrow but continuous feature that separates Florida Bay from the coastal wetlands. Simulated surface-water flow patterns in Taylor Slough indicate southwesterly flow in the northern part of the model area with a gradual change in flow direction toward the southeast into Joe Bay and through Trout Creek. For the five creeks with continuous discharge measurements for the 7-year simulation period (McCormick, Mud, Trout, Taylor River, and West Highway), the simulated cumulative discharge is only about 15 percent less than the measured cumulative discharge. Of the 10 coastal creeks, Trout Creek is the largest contributor of freshwater to Florida Bay (47 percent) with West Highway (12 percent) and East Creek (10 percent) as the next largest contributors.

In addition to creek flows, the model also simulates overtopping of the Buttonwood Embankment and submarine ground-water discharge as mechanisms for delivering freshwater from the coastal wetlands into Florida Bay. Although simulated estimates of Buttonwood Embankment overtopping contain a high level of uncertainty, model results indicate that overtopping is infrequent, but can occur in response to tropical storms. Storm surges force brackish Florida Bay water over the embankment and into the coastal wetlands. After making landfall, a tropical storm can also produce enough rain to reverse embankment overflow from the coastal wetland into Florida Bay. For the 7-year simulation period, the net embankment overflow, which is into Florida Bay, is only about 1.5 percent of the combined coastal creek flow. The water budget for the coastal wetland part of the model domain indicates that average rates of downward leakage $(17.42 \mathrm{~cm} / \mathrm{yr})$ and upward leakage $(17.14 \mathrm{~cm} / \mathrm{yr})$ are nearly identical for the simulation period, but for any particular year, however, the wetland may experience a net loss or gain to or from the aquifer. Model results also indicate that submarine ground-water discharge may be occurring on the south side of the embankment in response to the higher surface-water levels in the coastal wetland. A field survey would be necessary to determine the validity of this model result.

Field data and model results indicate a strong seasonal pattern in coastal wetland salinities. Salinities at the coastal creeks reach 35 psu toward the end of the dry season, but quickly drop to less than 5 psu with the onset of the wet season. This seasonal flushing pattern is well represented by the model with mean absolute errors in simulated salinity ranging between 4 and 7 psu for the five coastal creeks with continuous data for the 7-year simulation period. Future modifications to the water-management system in southern Florida may alter the freshwater deliveries to the Taylor Slough area. Based on the performance of the model to match the seasonal flushing pattern, the model should be able to predict the effects of these altered water deliveries on coastal salinity patterns. 
The effects of surface-water and ground-water interactions, density-dependent flow, and local wind stress were evaluated by performing simulations without these processes and comparing results with the base case simulation. In general, the surface-water model that neglects interactions with ground water compares worse with field data than the base case integrated model; however, without additional leakage measurements, the better match with the integrated model cannot be conclusively attributed to groundwater interactions. A constant-density simulation results in cumulative creek flows that are about 9 percent less than the base case, and only a slightly different pattern in leakage, suggesting that the upward leakage zone that coincides with the freshwater/saltwater interface in the Biscayne aquifer is caused by topographic variations rather than by density variations. Removing the local wind stress does not have a substantial effect on creek flows, but does affect coastal salinities. Without the local wind stress, Trout Creek salinities do not increase to the 30-35 psu values measured in the field during the dry season.

In general, comparisons between simulated and observed flow and salinity patterns in both the wetland and aquifer indicate that important system processes and behavior are represented by the model, and although the model is subject to limitations, it is well suited to predict the effects of Everglades restoration on the Taylor Slough coastal wetlands. The general approach described here would also be applicable to other coastal wetlands where restoration or contaminant transport issues are of concern. The integrated code is robust, accurate, and can represent hydrodynamic surface-water flow and variable-density ground-water flow for multi-year periods.

\section{Acknowledgments}

This study was funded by the U.S. Geological Survey Greater Everglades Priority Ecosystems Science Program and by the Everglades National Park Critical Ecosystem Studies Initiative. The authors are grateful to John Wang, Mark Zucker, and Eve Kuniansky for providing substantial technical reviews of the manuscript.

\section{References Cited}

Bakker, M., A Dupuit formulation for modeling seawater intrusion in regional aquifer systems, Water Resour. Res., 39(5), 1131, doi:10.1029/2002WR001710, 2003.

Bakker, M., G.H.P. Oude Essink, and C.D. Langevin, The rotating movement of three immiscible fluids-a benchmark problem, J. Hydrol (287) 270-278, 2004.

Bales, J.D., and J.C. Robbins, Simulation of hydrodynamics and solute transport in the Pamlico River Estuary, North Carolina, U.S. Geol. Surv. Open-File Rep. 94-454, 85 pp., 1995.

Brown, G.L., R.T. McAdory, G.H. Nail, M.S. Sarruff, R.C. Berger, and M.A. Granat, Development of a two-dimensional numerical model of hydrodynamics and salinity for Biscayne Bay, FL, U.S. Army Corps of Engineers Technical Rep. CHL-03-10, 2003.

Corbett, D.R., J. Chanton, W. Burnett, K. Dillon, and C. Rutkowski. Patterns of groundwater discharge into Florida Bay. Limnology and Oceanography (44) 4, 1045-1055, 1999.

Desmond, G., 2003, Measuring and mapping the topography of the Florida Everglades for ecosystem restoration in U.S. Geological Survey Greater Everglades Science Program: 2002 Biennial Report April 13-18, 2003, U.S. Geol Surv. Open-File Rep. 03-54, 31-32, 2003.

Fairbanks, J., S. Panday, and P.S. Huyakorn, Comparisons of linked and fully coupled approaches to simulating conjunctive surface/subsurface flow and their interactions, in MODFLOW 2001 and Other Modeling Odysseys, Conference Proceedings, Golden, Colorado, edited by Seo, B., Poeter, E., and C. Zheng, pp. 356-361, 2001.

Fischer, H.B., J.E. List, R.C.Y. Koh, and others, Mixing in inland and coastal waters: New York, N.Y., Academic Press, pp. 126127, 263, 1979.

Fish, J.E., and M.T. Stewart, Hydrogeology of the surficial aquifer system, Dade County, Florida: U.S. Geol. Surv. Water-Res. Invest. Rep. 90-4108, 50 p., 1991.

Fitterman, D.V., and M. Deszcz-Pan, Helicopter EM mapping of saltwater intrusion in Everglades National Park, Florida Exploration Geophysics, 29, 240-243, 1998.

Fitterman, D.V., M. Deszcz-Pan, and C.E. Stoddard, Results of time-domain electromagnetic soundings in Everglades National Park, Florida, U.S. Geol. Surv. Open-File Rep. 99-426, 1999.

German, E.R., Regional evaluation of evapotranspiration in the Everglades, in Proceedings of the 3rd International Symposium on Ecohydraulics, Salt Lake City, Utah, July 13-16, 1999.

German, E.R., Regional evaluation of evapotranspiration in the Everglades: U.S. Geol. Surv. Water-Res. Invest. Rep. 00-4217, 48 pp. $2000 a$ 


\section{Simulation of Integrated Surface-Water/Ground-Water Flow and Salinity for a Coastal Wetland and Adjacent Estuary}

German, E.R., Regional evaluation of evapotranspiration in the Everglades, in U.S. Geological Survey Program on the South Florida Ecosystem: 2000 Proceedings of the Greater Everglades Ecosystem Restoration (GEER) Conference, December 11-15, 2000, edited by Eggleston and others, U.S. Geol. Surv. Open-File Rep. 00-449, pp. 21-23, 2000b,

Goodwin, C.R., Tidal-flow, circulation, and flushing changes caused by dredge and fill in Tampa Bay, Florida, U.S. Geol. Surv. Water-Supply. Paper 2282, 88 pp., 1987.

Goodwin, C.R., Tidal-flow, circulation, and flushing changes caused by dredge and fill in Hillsborough Bay, Florida, U.S. Geol. Surv. Water-Supply Paper 2376, 49 pp., 1991.

Goodwin, C.R., Simulation of tidal-flow, circulation, and flushing of the Charlotte Harbor Estuarine System, Florida, U.S. Geol. Surv. Water-Res. Invest. Rep. 93-4153, 92 p., 1996.

Graham, D.N., and A. Refsgaard, 2001, MIKE SHE: A distributed, physically based modeling system for surface water/groundwater interactions, in MODFLOW 2001 and Other Modeling Odysseys, Conference Proceedings, Golden, Colorado, edited by Seo, B., Poeter, E., and C. Zheng, 321-327, 2001.

Green, W.H. and G. Ampt, Studies of soil physics, part I - the flow of air and water through soils. J. Ag. Sci. 4:1-24., 1911.

Guo, W., and G.D. Bennett, Simulation of saline/fresh water flows using MODFLOW, in MODFLOW' 98 Conference, Golden, Colorado, 1998, Proceedings (1), edited by E. Poeter, and others, 267-274, 1998.

Guo, W., and C.D. Langevin, User's guide to SEAWAT: A computer program for simulation of three-dimensional variable-density ground-water flow: U.S. Geol. Surv. Open-File Rep. 01-434, 79 pp, 2002.

Hansen, M., and N.T. DeWitt, 1890 and 1990 bathymetry of Florida Bay, U.S. Geol. Surv. Open-File Rep. 00-347, http:// sofia.usgs.gov/publications/ofr/00-347/, 2000.

Harvey, J.W., J. Choi, and R.H. Mooney, Hydrologic interactions between surface water and ground water in Taylor Slough, Everglades National Park, in U.S. Geological Survey Program on the South Florida Ecosystem: 2000 Proceedings of the Greater Everglades Ecosystem Restoration (GEER) Conference, December 11-15, 2000, edited by Eggleston and others, U.S. Geol. Surv. Open-File Rep. 00-449, pp. 24-26, 2000a.

Harvey, J.W., J.M. Jackson, R.H. Mooney, and J. Choi, Interactions between ground water and surface water in Taylor Slough and Vicinity, Everglades National Park, south Florida: Study Methods and Appendixes. U.S. Geol. Surv. Open-File Rep. 00-483, $67 \mathrm{pp}, 2000 \mathrm{~b}$.

Hittle, C.D., Quantity, timing, and distribution of freshwater flows into northeastern Florida Bay, in U.S. Geological Survey Program on the South Florida Ecosystem: 2000 Proceedings of the Greater Everglades Ecosystem Restoration (GEER) Conference, December 11-15, 2000, edited by Eggleston and others, U.S. Geol. Surv. Open-File Rep. 00-449, pp. 27-28, 2000.

Hittle, C.D., E. Patino, and M.A. Zucker, Freshwater flow from estuarine creeks into northeastern Florida Bay: U.S. Geol. Surv. Water-Res. Invest. Rep. 01-4164, 32 p., 2001.

Holmes, C.W., J. Robbins, R. Halley, and others, Sediment dynamics of Florida Bay mud banks on a decadal time scale, in U.S. Geological Survey Program on the South Florida Ecosystem: 2000 Proceedings of the Greater Everglades Ecosystem Restoration (GEER) Conference, December 11-15, 2000, edited by Eggleston and others, U.S. Geol. Surv. Open-File Rep. 00-449, pp. 108, 2000.

HydroGeoLogic Inc., MODHMS - A Comprehensive MODFLOW-based Hydrologic Modeling System, Version 2.1, HydroGeoLogic Inc., Herndon, Virginia, 2003.

Jarosewich, M. and J. Wagner, Geologic structure of the surficial aquifer system underlying Everglades National Park and the Big Cypress National Preserve, 43pp, Everglades National Park, South Florida Research Center, Homestead, Florida, 1985.

Jenter, H.L., and M.P. Duff 1999, Locally-forced wind effects on shallow waters with emergent vegetation, in Proceedings of the 3rd International Symposium on Ecohydraulics, Salt Lake City, Utah, July 13-16, 1999.

Juster, T.C., Circulation of saline and hypersaline groundwater in carbonate mud: mechanisms, rates, and an example from Florida Bay, Ph.D. Dissertation, University of South Florida, Tampa, Florida. 215 p., 1995.

Kohout, F.A., The flow of fresh water and salt water in the Biscayne aquifer of the Miami area, Florida, in Sea Water in Coastal Aquifers: U.S. Geol. Surv. Water-Supply Paper 1613-C, pp. 12-32, 1964

Knight, E.L., K. Kotun, and F.E. James, An evaluation of the hydrologic conditions resulting from Hurricane Irene in Everglades National Park, DRAFT. 94. pp. South Florida Natural Resources Center, Everglades National Park, Homestead, Florida, 2000.

Langevin, C.D., Simulation of ground-water discharge to Biscayne Bay, Southeastern Florida: U.S. Geol. Surv. Water-Res. Invest. Rep. 00-4251, 127 pp., 2001.

Langevin, C.D., Simulation of submarine ground water discharge to a marine estuary: Biscayne Bay, Florida, Ground Water 4l(6), 758-771, 2003.

Langevin, C.D., W.B. Shoemaker, and W. Guo, MODFLOW-2000, the U.S. Geological Survey modular ground-water model - documentation of the SEAWAT-2000 version with the variable-density flow process (VDF) and the integrated MT3DMS transport process (IMT), U.S. Geol. Surv. Open-File Rep. 03-426, 43 p., 2003.

Large, W.G., and S. Pond, Open ocean momentum flux measurements in moderate to strong winds, J. Phys. Oceanog., 11, p. 324336, 1981. 
Lee, J.K., V. Carter, and N.B. Rybicki, Determining flow-resistance coefficients in the Florida Everglades, in Proceedings of the 3rd International Symposium on Ecohydraulics, Salt Lake City, Utah, July 13-16, 1999.

Lee, J.K., H.L. Jenter, V.C. Lai, and others, A pipe manometer for the determination of very small water-surface slopes in the Florida Everglades, in U.S. Geological Survey Program on the South Florida Ecosystem: 2000 Proceedings of the Greater Everglades Ecosystem Restoration (GEER) Conference, December 11-15, 2000, edited by Eggleston and others, U.S. Geol. Surv. Open-File Rep. 00-449, pp. 31-32, 2000,

Leendertse, J.J., A Water-quality simulation model for well-mixed estuaries and coastal seas: Volume IV, Jamaica Bay tidal flows: New York, 48 p., The New York City Rand Institute, R-1009-NYC, 1972.

Leendertse, J.J., Aspects of SIMSYS2D, a system for two-dimensional flow computation: Santa Monica, Calif., Rand Corporation Report R-3572-USGS, 80 p., 1987.

Leendertse, J.J., A. Langerak, and M.A.M. de Ras, Two-dimensional tidal models for the Delta Works, in Transport models for inland and coastal waters, proceedings of a symposium on predictive ability, edited by H.B. Fischer, Academic Press, New York, 1981.

Leendertse, J.J., and E.C. Gritton, A water-quality simulation model for well-mixed estuaries and coastal seas: Volume II, Computation procedures: 48pp. New York, The New York City Rand Institute, R-708-NYC, 1971.

Lusczynski, N.J., Head and flow of ground water of variable density, Jour. of Geophys. Res., (66) 4247-4256, 1961.

McDonald, M.G., and A.W. Harbaugh, A modular three-dimensional finite-difference ground-water flow model: U.S. Geol. Surv. Techniques of Water Res. Invest., Book 6, chapter A1, 586 pp., 1988.

McDonald, M.G., Harbaugh, A.W., Orr, B.R., and Ackerman, D.J., A method of converting no-flow cells to variable-head cells for the U.S. Geological Survey modular finite-difference ground-water flow model: U.S. Geol. Surv. Open-File Rep. 91-536, 99 p., 1992.

Merritt, M.L., Simulation of the water table altitude in the Biscayne aquifer, southern Dade County, Florida, water years 1945-89, U.S. Geol. Surv. Water-Supply Paper 2458, 148 p., 1996a.

Merritt, M.L., Numerical simulation of a plume of brackish water in the Biscayne aquifer originating from a flowing artesian well, Dade County, Florida, U.S. Geol. Surv. Water-Supply Paper 2464, 74 pp., 1996b.

Nuttle, W.K., J.W. Forqurean, B.J. Cosby, J.C. Zieman, and M.B. Robblee, Influence of net freshwater supply on salinity in Florida Bay, Water Resour. Res., 36(7), 1805-1822., 2000.

Panday, S. and P.S. Huyakorn, A Fully Coupled Physically-Based Spatially-Distributed Model for Evaluating Surface/Subsurface Flow, Advances in Water Resour., in press, 2004.

Prager, E., and R. Halley, Florida Bay Bottom Types, U.S. Geol. Surv. Open-File Rep. 97-526, 1 p., 1997.

Price, R.M., Geochemical determinations of groundwater flow in Everglades National Park, Ph.D. Dissertation, University of Miami, Coral Gables, Florida. 235 p., 2001.

Reid, R.O., and R.E. Whitaker, Wind-driven flow of water influenced by a canopy, Journal of the Waterways, Harbors, and Coastal Engineering Division, 102 (WW1), 61-77, 1976.

Richards, L.A., Capillary conduction of liquids through porous mediums, Physics, 1, pp. 318-333, 1931.

Robbins, J.C., and J.D. Bales, Simulation of hydrodynamics and solute transport in the Neuse River Estuary, North Carolina, U.S. Geol. Surv. Open-File Rep. 94-511, 85 p., 1995.

Sonenshein, R.S., Delineation and extent of saltwater intrusion in the Biscayne aquifer, Eastern Dade County, Florida, 1995, U.S. Geol. Surv. Water-Res. Invest. Rep. 96-4285, 1 sheet, 1997.

Stewart, M.A., T.N. Bhatt, R.J. Fennema, and D.V. Fitterman, The road to Flamingo: An evaluation of flow pattern alterations and salinity intrusion in the lower glades, Everglades National Park, U.S. Geol. Surv. Open-File Rep. 02-59, 36 pp., 2002.

Swain, E.D., B. Howie, and J. Dixon, Description and field analysis of a coupled ground-water/surface-water flow model (MODFLOW/BRANCH) with modifications for structures and wetlands in southern Dade County, Florida, U.S. Geol. Surv. WaterRes. Invest. Rep. 96-4118, 67 p., 1996.

Swain, E.D., M. Wolfert, J.D. Bales, and C.R. Goodwin, Two-dimensional hydrodynamic simulation of surface-water flow and transport to Florida Bay through the Southern Inland and Coastal Systems (SICS), U.S. Geol. Surv. Water Res. Invest. Rep. 034287, 56 p., 2004.

Tillis, G.M., Measuring Taylor Slough boundary and internal flows, Everglades National Park, Florida: U.S. Geol. Surv. Open-File Rep. 01-225, 16 p., 2001.

VanderKwaak, J.E., Numerical simulation of flow and chemical transport in integrated surface-subsurface hydrologic systems, Ph.D. Dissertation, Dept. of Earth Sciences, University of Waterloo, Ontario, Canada, 217 p., 1999.

VanderKwaak, J.E., and K. Loague, Hydrologic-response simulations for the R-5 catchment with a comprehensive physics-based model, Water Resour. Res. 37(4) 999-1013, 2001.

Wang, J.D., J. Luo, and J.S. Ault, Flows, salinity, and some implications for larval transport in South Biscayne Bay, Florida, Bull. Marine Sci., 73(3), 695-723, 2003. 
Yeh, G. T. and G.B. Huang, A Numerical Model to Simulate Water Flow in Watershed Systems of 1-D Stream-River Network, 2D Overland Regime, and 3-D Subsurface Media (WASH123D: Version 1.5), Technical Report. Dept. of Civil and Environmental Engineering, University of Central Florida, Orlando, Florida, 2003

Zheng, C., and P.P. Wang, MT3DMS-A modular three-dimensional multispecies transport model for simulation of advection, dispersion and chemical reactions of contaminants in ground-water systems; documentation and user's guide, U.S. Army Corps of Engineers Contract Report SERDP-99-1, 1999. 